\title{
Direct observations of the atmospheric processing of Asian mineral dust
}

\author{
R. C. Sullivan ${ }^{1}$, S. A. Guazzotti ${ }^{1,{ }^{*}}$, D. A. Sodeman ${ }^{1,{ }^{* *}}$, and K. A. Prather ${ }^{1,2}$ \\ ${ }^{1}$ Department of Chemistry \& Biochemistry, University of California, San Diego, La Jolla, CA 92093-0314, USA \\ ${ }^{2}$ Scripps Institution of Oceanography, University of California, San Diego, La Jolla, CA 92093, USA \\ * now at: Nanostream, Inc., 580 Sierra Madre Villa, Pasadena, CA 91107, USA \\ ** now at: Desert Research Institute, Reno, NV 89512, USA
}

Received: 6 March 2006 - Published in Atmos. Chem. Phys. Discuss.: 23 May 2006

Revised: 6 February 2007 - Accepted: 9 February 2007 - Published: 22 February 2007

\begin{abstract}
The accumulation of secondary acids and ammonium on individual mineral dust particles during ACEAsia has been measured with an online single-particle mass spectrometer, the ATOFMS. Changes in the amounts of sulphate, nitrate, and chloride mixed with dust particles correlate with air masses from different source regions. The uptake of secondary acids depended on the individual dust particle mineralogy; high amounts of nitrate accumulated on calcium-rich dust while high amounts of sulphate accumulated on aluminosilicate-rich dust. Oxidation of S(IV) to $\mathrm{S}(\mathrm{VI})$ by iron in the aluminosilicate dust is a possible explanation for this enrichment of sulphate, which has important consequences for the fertilization of remote oceans by soluble iron. This study shows the segregation of sulphate from nitrate and chloride in individual aged dust particles for the first time. A transport and aging timeline provides an explanation for the observed segregation. Our data suggests that sulphate became mixed with the dust first. This implies that the transport pathway is more important than the reaction kinetics in determining which species accumulate on mineral dust. Early in the study, dust particles in volcanically influenced air masses were mixed predominately with sulphate. Dust mixed with chloride then dominated over sulphate and nitrate when a major dust front reached the R. V. Ronald Brown. We hypothesize that the rapid increase in chloride on dust was due to mixing with $\mathrm{HCl}(\mathrm{g})$ released from acidified sea salt particles induced by heterogeneous reaction with volcanic $\mathrm{SO}_{2}(\mathrm{~g})$, prior to the arrival of the dust front. The amount of ammonium mixed with dust correlated strongly with the total amount of secondary acid reaction products in the dust. Submicron dust and ammonium sulphate were internally mixed, contrary to frequent reports that they exist as external mixtures. The size distribution of the mixing
\end{abstract}

Correspondence to: K. Prather

(kprather@ucsd.edu) state of dust with these secondary species validates previous mechanisms of the atmospheric processing of dust and generally agrees with simulated aerosol chemistry from the STEM-2K3 model. This series of novel results has important implications for improving the treatment of dust in global chemistry models and highlights a number of key processes that merit further investigation through laboratory and field studies.

\section{Introduction}

Major dust storm events typically develop in China in the spring, brought about by cold frontal systems and the Mongolian cyclonic depression (Sun et al., 2001). The Gobi Deserts in Mongolia and northern China, and the Taklimakan Desert in western China, are the two dominant source regions of dust in east Asia. Once lofted to high altitudes, dust can then become entrained in the jet stream and may be transported long distances over the Pacific Ocean to North America (Cahill, 2003; Duce et al., 1980; Jaffe et al., 1999; Thulasiraman et al., 2002). The Asian Pacific Regional Aerosol Characterization Experiment (ACE-Asia) in 2001 was designed to study the impact these spring dust events have on the physical, chemical and radiative properties of the Asian aerosol as it is transported over the mainland and the Pacific Ocean (Huebert et al., 2003; Seinfeld et al., 2004).

Mineral dust represents the second largest component of primary particle emissions by mass, with an estimated global source strength of 1000 to $3000 \mathrm{Mt} / \mathrm{yr}$ (Ginoux et al., 2001; Houghton et al., 2001). Laboratory studies have demonstrated the uptake of reactive gases including $\mathrm{O}_{3}$ (Chang et al., 2005; Hanisch and Crowley, 2003b; Sullivan et al., 2004; Usher et al., 2003b), $\mathrm{NO}_{\mathrm{x}}$ (Grassian, 2002; Hanisch and Crowley, 2003a), $\mathrm{NO}_{\mathrm{y}}$ (e.g. $\mathrm{HNO}_{3}, \mathrm{NO}_{3}$,

Published by Copernicus GmbH on behalf of the European Geosciences Union. 
$\mathrm{N}_{2} \mathrm{O}_{5}$ ) (Al-Hosney and Grassian, 2005; Hanisch and Crowley, 2001; Karagulian and Rossi, 2005; Krueger et al., 2004; Santschi and Rossi, 2006; Seisel et al., 2005; Underwood et al., 2001; Vlasenko et al., 2006), $\mathrm{SO}_{2}$ (Ullerstam et al., 2003), and organics (Al-Hosney et al., 2005; Carlos-Cuellar et al., 2003) on dust particles (Usher et al., 2003a). Dust particles present a large surface area for heterogeneous reactions to occur on, and alter radiative transfer and rates of photolysis. Thus dust influences the chemical composition of the troposphere, as demonstrated by numerous field and modeling studies (Bauer et al., 2004; Bian and Zender, 2003; de Reus et al., 2000; Dentener et al., 1996; Seinfeld et al., 2004; Tang et al., 2004a). Mineral dust particles can become internally mixed with secondary species such as ammonium sulphate, ammonium nitrate, hydrochloric acid, sea salt, and biomass burning particles through coagulation, cloud processing, and heterogeneous reactions (Andreae et al., 1986; Clarke et al., 2004; Guazzotti et al., 2001a; Korhonen et al., 2003; Mamane and Gottlieb, 1989; Mori et al., 1998; Song and Carmichael, 1999; Yin et al., 2002; Zhang and Iwasaka, 2004; Zhang et al., 2003). These processes modify the chemical composition of the dust-laden aerosol and this can alter the radiative properties of the dust aerosol. The addition of water-soluble secondary species to a dust particle can affect its ability to act as a cloud or ice nucleus and thus influences the indirect climate forcing of dust (Cziczo et al., 2004; DeMott et al., 2003; Gibson et al., 2006; Levin et al., 1996; Levin et al., 2005; Matsumoto et al., 2006; Perry et al., 2004; Rudich et al., 2002; Yin et al., 2002). Mineral dust particles have been observed to increase cloudiness by producing more but smaller droplets, with potential reductions in precipitation (Kaufman et al., 2005; Rosenfeld et al., 2001). Photochemical processes and the uptake of secondary acids and organics can also increase the solubility and bioavailability of iron in dust particles, which is an important pathway for the fertilization of remote oceans with subsequent climate impacts (Bishop et al., 2002; Jickells et al., 2005; Meskhidze et al., 2003). Mineral dust mixed with nitrate is also an important vector for nitrogen fertilization of oceans (Baker et al., 2003; Prospero and Savoie, 1989).

Asian mineral dust particles at their original source location are primarily composed of mixtures of quartz, clays, micas, feldspars, carbonates (primarily calcite, $\mathrm{CaCO}_{3}$ ), and other minor minerals (Gao and Anderson, 2001; Honda et al., 2004; Pye, 1987; Trochkine et al., 2003; Usher et al., 2003a; Yuan et al., 2004). The mineralogy of $\mathrm{PM}_{10}$ collected during severe Asian dust events in 2000 and 2002 in Beijing was determined by Shi et al. (2005) to be primarily clay minerals $(>40 \%)$, followed by noncrystalline materials and quartz (both around 19\%), with smaller amounts of calcite, plagioclase, K-feldspar, pyrite and other trace minerals. Surface measurements made in Beijing by Matsuki et al. (2005a) classified $28 \%$ of the Asian dust particles as calcite. The high carbonate fraction of Chinese dust is significant and this alkaline mineral has been shown to react readily with acidic species such as $\mathrm{HNO}_{3}$ to form $\mathrm{Ca}\left(\mathrm{NO}_{3}\right)_{2}$ and liberate $\mathrm{CO}_{2}(\mathrm{~g})$ (Hanisch and Crowley, 2001; Johnson et al., 2005; Kelly and Wexler, 2005; Krueger et al., 2004; Laskin et al., 2005; Matsuki et al., 2005b; Song and Carmichael, 2001).

In April 2001, a major dust storm event transported highly elevated levels of dust particles to the various ground, ship, and aircraft sampling platforms during ACE-Asia. The principal source regions of the dust during these events were the Taklimakan desert in Xinjiang Province, China and the desert regions in Mongolia, including the Gobi desert (Gong et al., 2003). Previous analyses of the dust storm aerosol produced a number of interesting and unique results. As the mineral dust aerosol was transported over China, Korea, and Japan to the ocean, it became mixed with anthropogenic, volcanic, and natural aerosols and aerosol precursor gases. When sampled onboard the R/V Ronald H. Brown in the Sea of Japan, the resulting aerosol was a complex mixture of mineral dust, organic carbon, elemental carbon, sulphates, nitrates, ammonium, and sea salt (Arimoto et al., 2006; Bates et al., 2004; Seinfeld et al., 2004). Results obtained with an aerosol timeof-flight mass spectrometer (ATOFMS) revealed that prior to the dust front, the majority of supermicron particulate-nitrate was internally mixed with aged sea salt particles. After the dust front, the particulate-nitrate was found to be predominantly internally mixed with mineral dust particles (Arimoto et al., 2006; Bates et al., 2004; Tang et al., 2004b). ATOFMS results further demonstrated the significant uptake of chlorine by mineral dust particles during the dust event (Sullivan et al., $2006^{1}$ ).

The results presented here further investigate the chemical aging of the mineral dust particles as mixing occurs with trace gases, and natural and anthropogenic aerosols. Our analysis provides new insights into the competitive uptake of different secondary acids by mineral dust and the role that the varying mineralogy of dust plays in these processes, processes that are now being incorporated into chemical models (Krueger et al., 2004; Laskin et al., 2005; Matsuki et al., 2005a, b; Tang et al., 2004b).

\section{Methods and instrumentation}

A transportable aerosol time-of-flight mass spectrometer (ATOFMS) located on the R/V Ronald H. Brown (RHB) was used to characterize the size and chemical composition of individual particles in real-time during the ACE-Asia campaign. The RHB left Hawaii on 16 March 2001 (DOY 75) and spent 10 days in transit to Japan. From DOY 90-99 the RHB circled around the southern end of Japan and into the Sea of Japan. On DOY 99 the RHB turned around and headed south out of the Sea of Japan through the Straits

\footnotetext{
${ }^{1}$ Sullivan, R. C., Guazzotti, S. A., Sodeman, D. A., Tang, Y. H., Carmichael, G. R., and Prather, K. A.: Mineral dust is a sink for chlorine in the marine boundary layer, Atmos. Environ., submitted, 2006.
} 
of Korea, finally docking at Yokosuka, Japan on DOY 110. More details on the RHB's cruise track and the air masses it sampled are available in Bates et al. (2004).

The aerosol sampled by the ATOFMS was drawn through a $6 \mathrm{~m}$ sample mast from $\sim 18 \mathrm{~m}$ above sea level. The bottom $1.5 \mathrm{~m}$ of the mast was heated to maintain the relative humidity of the aerosol at $55 \pm 5 \%$. Air was only sampled when the relative wind speed and direction, and concentrations of particles larger than $15 \mathrm{~nm}$ indicated that the sampled air was free of local contamination (Bates et al., 2004).

The design and operation of the ATOFMS is described in detail elsewhere (Gard et al., 1997) and only a brief description is given here. The ATOFMS draws the aerosol sample through a converging nozzle into a differentially pumped vacuum chamber, accelerating each particle to its terminal velocity. The velocity of each particle is determined by the time-of-flight between two CW lasers. This velocity is converted to an aerodynamic diameter $\left(D_{a}\right)$ using a calibration curve generated with polystyrene latex spheres of discrete diameters. The particle's velocity also triggers the firing of a frequency-quadrupled Nd:YAG laser $(266 \mathrm{~nm})$ that desorbs and ionizes chemicals from each sized particle. A dual reflectron TOFMS records the mass spectra of the resulting positive and negative ions simultaneously. The ATOFMS employed during ACE-Asia was capable of efficiently detecting particles between $D_{a} 0.2$ and $3.0 \mu \mathrm{m}$.

A wide variety of mineral dust samples from Asian desert regions were collected in 2001. Mass spectra from each dust sample were obtained after the campaign by placing each dust sample into a flask in a sonicator to create a suspension of dust particles under nitrogen gas flow. The aerosol was then directed into the ATOFMS inlet for analysis and at least 2400 single-particle mass spectra were collected per sample.

Analysis of the single-particle mass spectra was performed using the Matlab® based toolkit YAADA (http://www.yaada. org) to perform searches for particular mass spectral features within the dataset. An adaptive resonance theory-based neural network algorithm, ART-2a, was used to group the data into clusters of particles with similar mass spectral features, using a vigilance factor of 0.80 (Song et al., 1999). Measurements made by the ATOFMS have previously been used to monitor heterogeneous reactions occurring on sea-salt, mineral dust, and secondary organic aerosols, as well as in cloud droplets, in real-time (Angelino et al., 2001; Bates et al., 2004; Gard et al., 1998; Sullivan and Prather, 2005 ${ }^{1}$; Tang et al., 2004b; Whiteaker and Prather, 2003).

\subsection{Filtering criteria}

The mineral dust particles classified by the ART-2a algorithm were further filtered to remove incorrectly classified biomass-burning particles and internal mixtures of dust and sea salt. As dust particles are transported through the troposphere they can become internally mixed with other particle types such as sea salt, particularly via cloud processing if the
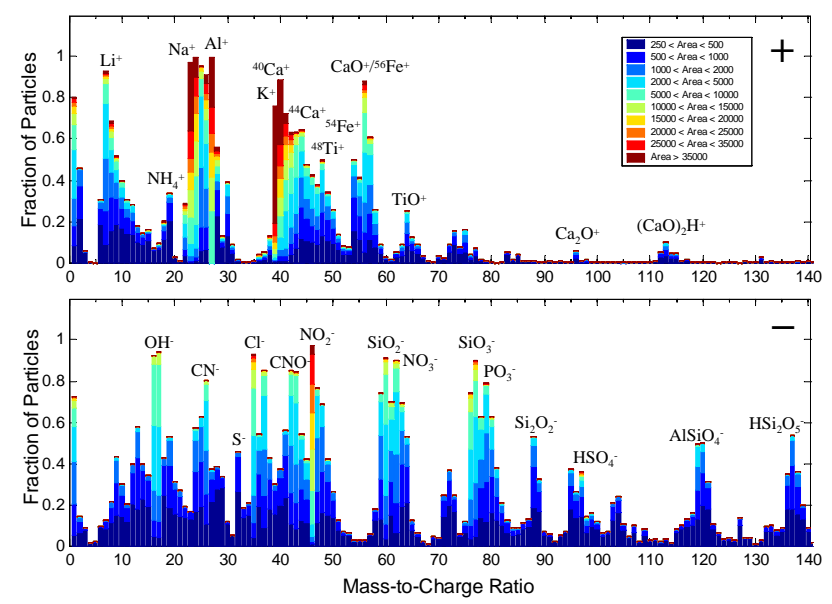

Fig. 1. Atmospherically processed mineral dust. Average digital mass spectrum of all 3634 filtered mineral dust particles detected during the dust front's passage over the RHB from DOY 101-101.3. Peaks are assigned to the most likely ions for dust particles (Table 1). The digital mass spectrum displays the fraction of particles that produced a peak area for each ion within a specified range. It reflects the range and homogeneity in the ion signal produced for a particular ion by an ensemble of particles.

dust aerosol passes through a cloudy region. The fraction of mineral dust particles internally mixed with sea salt has been reported to be as high as $85 \%$ after transport through marine regions (Andreae et al., 1986; Fan et al., 1996; Niimura et al., 1998; Zhang et al., 2003). To focus only on the mixing of secondary acid products with mineral dust particles, the contributions of chloride, nitrate, and sulphate from internal mixing of dust with sea salt were excluded by removing dust particles containing the ${ }^{81}\left[\mathrm{Na}_{2}{ }^{35} \mathrm{Cl}\right]^{+}$ion. The Appendix provides further details on the filtering criteria. The ensemble of dust particles filtered to exclude biomass and mixtures with sea salt, are referred to herein as "filtered mineral dust particles".

\section{Results and discussion}

\subsection{Mineral dust mass spectra}

A total of 731309 single-particle mass spectra were collected over the course of the campaign. Out of all of these particles, 220806 were classified as mineral dust upon sorting the particles into chemically similar groups using the ART-2a clustering algorithm (Song et al., 1999). The assignment as dust is based on similarities to source dust mass spectra discussed below, as well as those presented in Silva et al. (2000) and Guazzotti et al. (2001a). The average mass spectrum for filtered mineral dust particles detected during the dust storm frontal passage (DOY 100.8-101.3) is shown in Fig. 1. The height of each peak indicates the fraction of particles for 
Table 1. Ion assignments for commonly observed peaks from mineral dust particles and secondary species.

\begin{tabular}{|c|c|}
\hline Mass-to-charge ratio & Most probable ion assignment \\
\hline \multicolumn{2}{|c|}{ Mineral dust } \\
\hline+7 & $\mathrm{Li}^{+}$ \\
\hline+23 & $\mathrm{Na}^{+}$ \\
\hline+24 & $\mathrm{Mg}^{+}$ \\
\hline+27 & $\mathrm{Al}^{+}$ \\
\hline+39 & ${ }^{39} \mathrm{~K}^{+}$ \\
\hline+40 & $\mathrm{Ca}^{+}$ \\
\hline+41 & ${ }^{41} \mathrm{~K}^{+}$or $\left[\mathrm{Na}\left(\mathrm{H}_{2} \mathrm{O}\right)\right]^{+}$ \\
\hline+48 & $\mathrm{Ti}^{+}$ \\
\hline+54 & ${ }^{54} \mathrm{Fe}^{+}$ \\
\hline+56 & ${ }^{56} \mathrm{Fe}^{+}$or $[\mathrm{CaO}]^{+}$ \\
\hline+64 & {$[\mathrm{TiO}]^{+}$} \\
\hline+96 & {$\left[\mathrm{Ca}_{2} \mathrm{O}\right]^{+}$} \\
\hline+112 & {$\left[(\mathrm{CaO})_{2}\right]$} \\
\hline+113 & {$\left[(\mathrm{CaO})_{2} \mathrm{H}\right]$} \\
\hline-16 & $\mathrm{O}^{-}$ \\
\hline-17 & {$[\mathrm{OH}]^{-}$} \\
\hline-26 & {$[\mathrm{CN}]^{-}$} \\
\hline-42 & {$[\mathrm{CNO}]^{-}$} \\
\hline-43 & {$[\mathrm{AlO}]^{-}$} \\
\hline-60 & {$[\mathrm{AlO}(\mathrm{OH})]^{-}$or $\left[\mathrm{SiO}_{2}\right]^{-}$} \\
\hline-63 & {$\left[\mathrm{PO}_{2}\right]^{-}$} \\
\hline-76 & {$\left[\mathrm{AlO}_{2}(\mathrm{OH})\right]^{-}$or $\left[{ }^{28} \mathrm{SiO}_{3}\right]^{-}$} \\
\hline-77 & {$\left[{ }^{29} \mathrm{SiO}_{3}\right]^{-}$or $\left[\mathrm{H}^{28} \mathrm{SiO}_{3}\right]^{-}$} \\
\hline-79 & {$\left[\mathrm{PO}_{3}\right]^{-}$} \\
\hline-88 & {$\left[\mathrm{Si}_{2} \mathrm{O}_{2}\right]$ or $\left[\mathrm{FeO}_{2}\right]$} \\
\hline \multicolumn{2}{|c|}{ Secondary species } \\
\hline$+18 *$ & {$\left[\mathrm{NH}_{4}\right]^{+}$} \\
\hline+30 & $\mathrm{NO}^{+}$ \\
\hline-32 & $\mathrm{~S}^{-}$ \\
\hline$-35^{*}$ & ${ }^{35} \mathrm{Cl}^{-}$ \\
\hline-37 & ${ }^{37} \mathrm{Cl}^{-}$ \\
\hline-46 & {$\left[\mathrm{NO}_{2}\right]^{-}$} \\
\hline-48 & {$[\mathrm{SO}]^{-}$} \\
\hline$-62 *$ & {$\left[\mathrm{NO}_{3}\right]^{-}$} \\
\hline-64 & {$\left[\mathrm{SO}_{2}\right]^{-}$} \\
\hline-80 & {$\left[\mathrm{SO}_{3}\right]^{-}$} \\
\hline$-97 *$ & {$\left[\mathrm{HSO}_{4}\right]^{-}$} \\
\hline
\end{tabular}

* indicates the principle ions used to measure ammonium, chloride, nitrate, or sulphate in mineral dust particles

which each ion was detected, while the colour corresponds to the peak area range measured for that fraction of particles. Metals and metal oxides from minerals typical of dust particles are clearly evident in both the positive and negative ion spectra and their peak assignments are listed in Table 1, based on previous ATOFMS measurements (Guazzotti et al., 2001a, b; Pastor et al., 2003; Silva et al., 2000). The ART2a sorting algorithm split the dust particles into 23 particle clusters out of the 60 largest clusters, further evidence for the wide range of dust mineralogy at the single particle level. These Asian dust particles represent a complex mixture of numerous different minerals, as reported by previous studies (Andronova et al., 1993; Clarke et al., 2004; Gao and Anderson, 2001; Krueger et al., 2004; Pye, 1987; Trochkine et al., 2003; Yuan et al., 2004).

The large fraction $(>80 \%)$ of particles containing calcium marker ions $(m / z+40,+56,+96)$ agrees with the high calcium carbonate fraction typical of Asian mineral dust (Jeong and Chun, 2006). Krueger et al. (2004) reported the chemical composition of China Loess determined by $\mathrm{EDX}$ to be $39 \% \mathrm{Ca}, 31 \% \mathrm{Si}, 13 \% \mathrm{Mg}, 7 \% \mathrm{Al}, 4 \%$ $\mathrm{Na}, 3 \% \mathrm{Fe}$, and $1 \% \mathrm{~K}$ (atomic percent). Ca was determined to be mostly from carbonate minerals including calcite $\left(\mathrm{CaCO}_{3}\right)$ and dolomite $\left(\mathrm{CaMg}\left(\mathrm{CO}_{3}\right)_{2}\right)$. The fraction of carbonate in Asian dust has been reported to range from 1-12\% by mass (Andronova et al., 1993; Derbyshire et al., 1998; Honda et al., 2004; Nishikawa et al., 2000). The carbonate anion, $\mathrm{CO}_{3}{ }^{-2}$, generally occurs in low abundance in the mass spectrum and is obscured by the more abundant isobars $\left[\mathrm{SiO}_{2}\right]^{-}$and $\left[\mathrm{AlO}_{2} \mathrm{H}\right]^{-}$at $m / z-60$ in mineral particles. Thus, carbonate from calcite and dolomite cannot be directly determined using $m / z-60$. The presence of $\mathrm{CaCO}_{3}$ can be reliably inferred from Ca-containing cations including ${ }^{40} \mathrm{Ca}^{+},{ }^{56}[\mathrm{CaO}]^{+},{ }^{96}\left[\mathrm{Ca}_{2} \mathrm{O}\right]^{+}$, and ${ }^{113}\left[(\mathrm{CaO})_{2} \mathrm{H}\right]^{+}$. The ${ }^{56}[\mathrm{CaO}]^{+}$cation is likely formed via $\left[\mathrm{CaCO}_{3}\right]^{+} \rightarrow[\mathrm{CaO}]^{+}+$ $\mathrm{CO}_{2}$ (Bruynseels and Van Grieken, 1983).

The mass spectra contain ions corresponding to ammonium, chloride, nitrate, or sulphate ions referred to as "secondary species". The principal ions used throughout this paper to study each of these four secondary species are indicated by an asterisk $(*)$ in Table 1 . These peaks provide evidence of the accumulation of secondary species by mineral dust, as discussed below. Some of these species could be present in the dust at the source as minerals such as halite $(\mathrm{NaCl})$ and gypsum $\left(\mathrm{CaSO}_{4}\right)$. Falkovich et al. (2001) found sulphate (not from gypsum) in Saharan dust particles which they determined was not due to atmospheric processing. Thus, they concluded that other sources of sulphate such as deposition by rain or runoff added sulphate to the dust's surface. These processes could also be adding sulphate to the Asian dust described herein. As shown later, the ambient aged dust particles had very large ion signals and temporal variations for sulphate, indicating that the vast majority of the sulphate accumulated on the dust during atmospheric transport.

Asian dust samples from various source regions were collected during ACE-Asia and analyzed using an ATOFMS to create reference spectra of unprocessed mineral dust. The mass spectra of source dust particles from regions such as Zhenbettai (Shaanxi Province, China), Dunhuang (Gansu Province, China), and the CJ13 Certified Reference Asian Mineral Dust (Gansu Province, China) (Nishikawa et al., 2000) were collected (not shown) and compared to those 
of ambient mineral dust sampled during ACE-Asia. These represent likely sources of the mineral dust particles carried aloft from mainland China to the Sea of Japan during ACE-Asia (Gong et al., 2003). Similarities between mineral cations and anions for both source and ambient dust particles, as listed in Table 1, are readily apparent. However, when compared to the ambient dust spectra, the source dust particles have much lower frequencies and ion intensities from the secondary species ammonium, chloride, nitrate, and sulphate. Typical ranges of peak areas for secondary species measured in the source and aged dust are given in Appendix A. Thus, the source dust spectra provide a benchmark for the very low background amounts of these secondary species in Asian dust, a threshold above which peak areas and detection frequencies can serve as indications of atmospheric processing during transport.

\subsection{Campaign timeline and air mass history}

Over the course of the campaign, the RHB sampled air arriving from a wide variety of source regions, as identified by Bates et al. (2004). We use time periods corresponding to the same source regions herein. Mineral dust particles were commonly detected during the pre-frontal Marine and Polluted Korea \& Japan periods in low concentrations. From DOY 99.3-100.5 (UTC) the RHB sampled air that had passed over the Miyakejima volcano and Japan and a distinct dust layer was observed at an altitude of $5 \mathrm{~km}$ (Polluted Volcano period). A major dust storm reached the RHB on DOY 100.8 in the western Sea of Japan (Dust Front period). Upper level trajectories were from the north China/Mongolia desert region, while low-level trajectories extended across Korea and China. The passage of the front brought elevated levels of dust to the ship. The sub-10 $\mu \mathrm{m}$ dust concentrations reached $140 \mu \mathrm{g} \mathrm{m}^{-3}$ on DOY 102. From DOY 100 to 104 mineral dust composed $8-31 \%$ of submicron and up to $80 \%$ of supermicron mass (Arimoto et al., 2006). Dust continued to dominate the aerosol behind the front. From DOY 101.8-103.4, both upper and lower level trajectories crossed Korea and north China/Mongolia (Dust \& Korea period). From DOY 103.4-104.5 the RHB was in the Korean Strait and sampling air that came out of north China/Mongolia and had passed over Shanghai (Dust \& Shanghai period).

\subsection{Detection of secondary inorganic species in dust parti-} cles

Nitrate, sulphate, and chloride were the most commonly observed anions in the mineral dust and correspond to the products expected from mineral dust particles that have mixed with secondary acids, as well as acid anhydrides including $\mathrm{N}_{2} \mathrm{O}_{5}, \mathrm{SO}_{2}, \mathrm{NO}_{\mathrm{x}}$, etc. Although the exact mechanism that leads to the accumulation of these secondary species cannot be determined from this study, the presence of chloride, nitrate, and sulphate on dust is most likely due to the forma- tion of hydrochloric, nitric, and sulphuric acids on the dust. This could be the result of reactive gases (e.g. $\mathrm{SO}_{2}, \mathrm{NO}_{2}$ ) adsorbing on the dust and then being oxidised to their acidic forms, or from the direct uptake of acidic gases (e.g. $\mathrm{HCl}$, $\mathrm{HNO}_{3}, \mathrm{H}_{2} \mathrm{SO}_{4}$ ) or their ammonium salts (e.g. $\mathrm{NH}_{4} \mathrm{NO}_{3}$, $\left.\left(\mathrm{NH}_{4}\right)_{2} \mathrm{SO}_{4}\right)$. After the acids formed/adsorbed on the dust, they can be fully or partially neutralised by alkaline species in the dust (e.g $\mathrm{CaCO}_{3}$ ) or by alkaline gases (e.g. $\mathrm{NH}_{3}$ ). The ions formed from these secondary species by the ATOFMS cannot directly indicate if the species are acidic (i.e. protonated) or not. Therefore, we will refer to them as "secondary acid products" or simply "secondary acids" throughout our discussion, indicating that the chloride, nitrate, and sulphate found on the dust were most likely initially due to the formation/accumulation of secondary acids on the dust. The products of secondary species that reacted with mineral dust and other particle types are evaluated using the ions listed in Table 1. For this analysis chloride, nitrate, and sulphate were primarily determined using peaks at $m / z-35,-62$, and -97 , respectively. The peak at ${ }^{62}\left[\mathrm{NO}_{3}\right]^{-}$is used instead of the ${ }^{46}\left[\mathrm{NO}_{2}\right]^{-}$nitrate fragment because $m / z-62$ is not detected in the Asian dust source spectra. Thus, by using $m / z-62$ to detect nitrate in dust, we preclude any significant contribution from nitrate (or nitrite) that is already present in the dust before it is injected into the atmosphere. Recall that mixed dust-sea salt particles have been filtered out of the analysis.

The average mass spectrum for filtered mineral dust particles detected during the dust storm frontal passage (DOY 100.8-101.3) is shown in Fig. 1. Peaks typical of mineral dust particles discussed above and listed in Table 1 are clearly evident, and a large increase is observed in the fraction of particles producing ions indicative of secondary acid products including $\mathrm{m} / \mathrm{z}+30,-35,-46,-62,-80$, and -97 . These peaks were not significant in the source dust spectra. Changes in the relative amounts of four secondary inorganic species in the mineral dust particles are evaluated by averaging the peak area ratio for each species from all filtered dust particles detected in one hour, as shown in Fig. 2 for DOY 98-105, encompassing the prefrontal and postfrontal time periods. The peak area for a particular $m / z$ is divided by that particle's peak area at $m / z 27\left(\mathrm{Al}^{+}\right)$to account for shot-to-shot variations in the LDI laser power and the amount of laser energy absorbed by each particle. The peak area ratio is evaluated for each individual particle before the hourly average is calculated. Al was chosen as an internal standard because it is the most commonly detected species in mineral dust by ATOFMS and has been shown to remain stable as a function of particle size during atmospheric transport (Arimoto et al., 2006; Guazzotti et al., 2001a; Mori et al., 2003; Silva et al., 2000). The relative sensitivities of the ATOFMS to different compounds in mineral dust and other matrices have not been thoroughly evaluated. If, however, the particle matrix is not changing significantly, as is the case for the Asian mineral dust particles discussed in this paper, then it is 


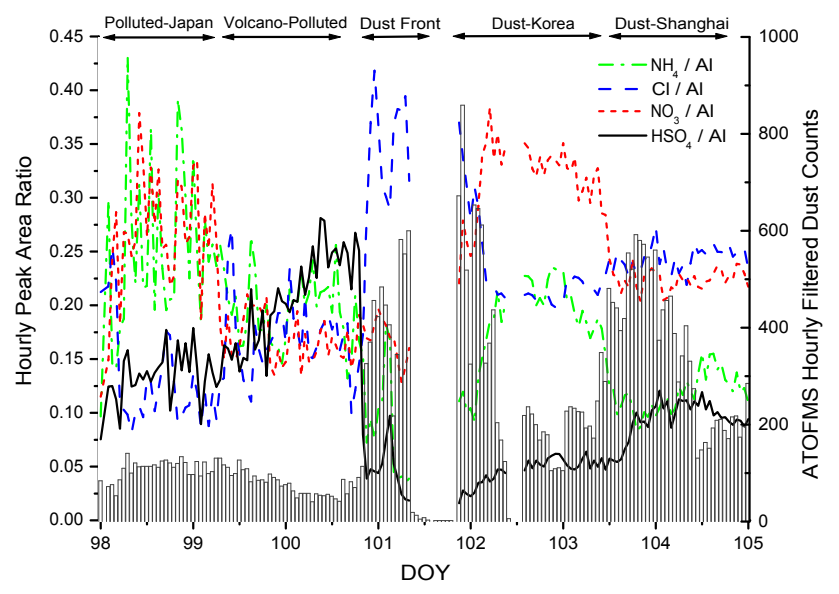

Fig. 2. Temporal evolution of secondary species in Asian mineral dust sampled aboard the RHB. Hourly averaged singleparticle peak area ratios (lines) from all filtered dust particles for four major secondary species: $\mathrm{NH}_{4}^{+}(m / z=18 / m / z=27)$, $\mathrm{Cl}^{-}(m / z=-35 / m / z=27), \mathrm{NO}_{3}^{-}(m / z=-62 / m / z=27)$, and $\mathrm{HSO}_{4}^{-}$ $(m / z=-97 / m / z=27)$. Total hourly ATOFMS dust particle counts (bars) are also displayed. Time periods corresponding to different air mass source regions as described by Bates et al. (2004) are indicated. All times are in UTC.

valid to compare the intensity of a particular peak from one particle to another and draw conclusions about the relative amounts of that specific species present in each particle.

\subsection{Temporal evolution of secondary species in Asian dust}

The principal peak area ratios for four major secondary species, ammonium, chloride, nitrate, and sulphate are plotted in Fig. 2. Gaps in the data occurred when aerosol sampling was suspended due to instrument maintenance or when the aerosol inlet was shut off during ship exhaust contamination periods. The total hourly ATOFMS dust particle counts are also displayed and indicate when the first dust front reached the RHB on DOY 100.8. To estimate the fraction of mineral dust particles internally mixed with chloride, nitrate, or sulphate, a peak area criterion $>5000$ units for either ${ }^{35} \mathrm{Cl}^{-},{ }^{62}\left[\mathrm{NO}_{3}\right]^{-}$or ${ }^{97}\left[\mathrm{HSO}_{4}\right]^{-}$was used to define a mineral dust particle as significantly mixed with one of these secondary species. This subset will be referred to as "reacted dust particles". This peak area criterion was chosen because it is much larger than peak areas for these ions in the original Asian source dust and ensures that only mineral dust particles that have become significantly aged during transport will be selected. The mass fraction of each acid corresponding to a peak area of 5000 has not yet been determined and is the subject of ongoing laboratory studies. This peak area is relatively large (see Appendix) and thus these results represent a conservative estimate of the degree to which mineral dust particles were processed and mixed with nitrate, chloride, and/or sulphate. Figure 3 shows the results of this clas-
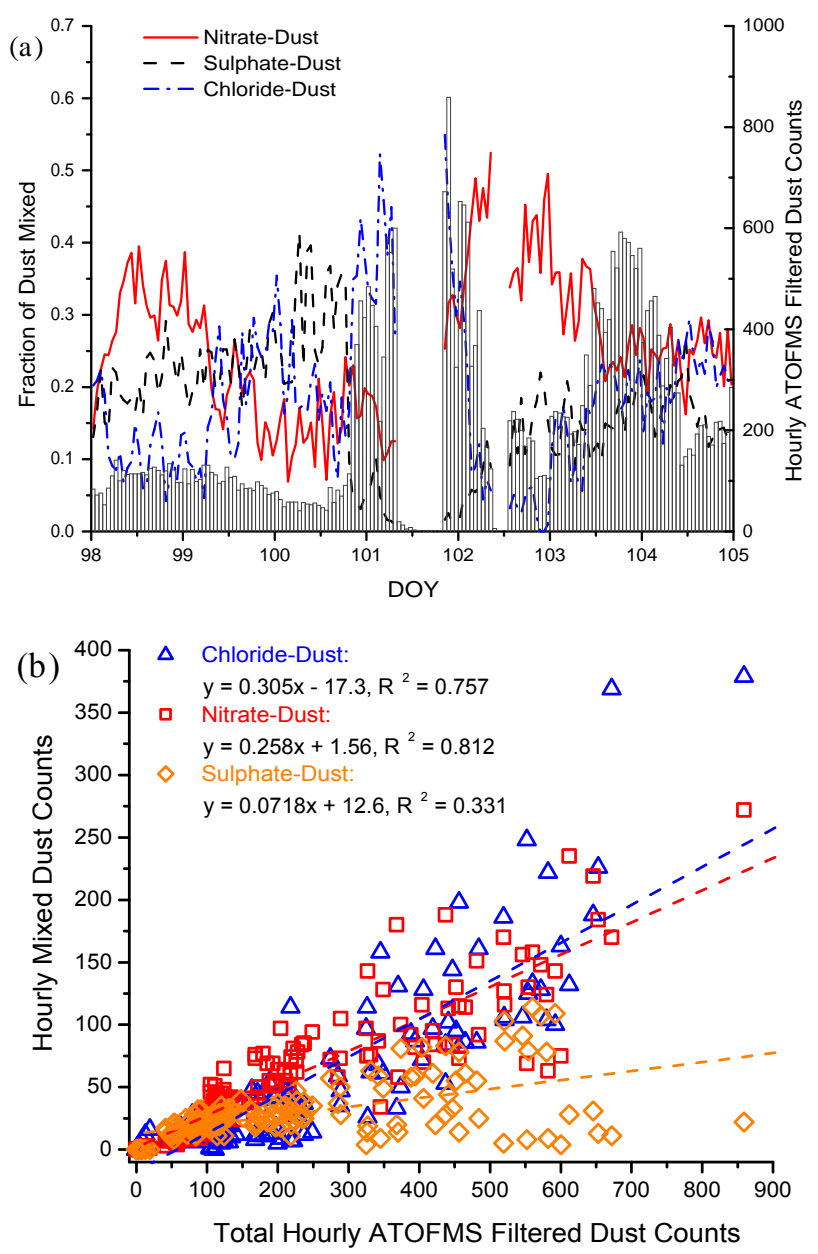

Fig. 3. Percentage of dust particles mixed with secondary acids. (a) Average hourly fraction (lines) of filtered dust particles defined as mixed with the indicated secondary acid product using the peak area $>5000$ criteria for ${ }^{35} \mathrm{Cl}^{-},{ }^{62}\left[\mathrm{NO}_{3}\right]^{-}$or ${ }^{97}\left[\mathrm{HSO}_{4}\right]^{-}$. The total filtered dust particle hourly counts are also displayed for reference (bars). (b) Scatter plot of the hourly counts of dust mixed with one of the three secondary acid products versus the total hourly ATOFMS dust counts, and their least-squares fits.

sification for the prefrontal and postfrontal periods. From DOY $98-105$, the average $( \pm 1 \sigma)$ fractions of dust particles mixed with nitrate, sulphate, or chloride were $25.9 \pm 9.6 \%$, $17.5 \pm 8.5 \%$, and $18.4 \pm 10.5 \%$, respectively.

The fraction of dust particles classified as mixed with each of the four secondary species is shown for each time period in Fig. 4. The hatched portion of the column indicates the fraction of dust particles that contained both a secondary acid product (e.g. nitrate) and ammonium. These mixing state statistics differ from the preliminary results presented in Arimoto et al. (2006). In that paper, the same criteria were used, but dust mixed with sea salt was not excluded from the analysis in order to present a picture of the fraction of dust mixed with acid products regardless of their source. Here 
we exclude dust internally mixed with sea salt to focus only on the role of secondary species produced in the atmosphere through chemical reactions.

Previous analyses of Asian mineral dust particles near their source show they typically have low concentrations of nitrate, sulphate and chloride (Andronova et al., 1993; Arimoto et al., 2004; Matsuki et al., 2005a; Mori et al., 2003; Nishikawa et al., 1991; Trochkine et al., 2003; Yuan et al., 2004; Zhang and Iwasaka, 1999). Thus, we conclude that these mineral dust particles accumulated secondary acids as they were transported from the desert regions over the polluted mainland and marine regions to the RHB, by either direct heterogeneous uptake, cloud processing, or coagulation with other secondary-containing aerosols such as ammonium nitrate/sulphate particles. From DOY 98 to 105, a substantial, though highly variable fraction of mineral dust was mixed with the secondary species chloride, nitrate, or sulphate (Figs. 3 and 4). Just before the dust front, from DOY 100-100.8, there were elevated levels of both sulphate and ammonium corresponding to the Polluted Volcano air mass. From approximately DOY 100.8-102, the relative amount of chloride in the mineral dust increased dramatically, coinciding with the arrival of the dust front, while the amount of ammonium simultaneously decreased. The amount of nitrate and ammonium both increased noticeably from DOY 102103.5. Dividing the peak areas of these species by a stable dust component, aluminium, provides further evidence for a secondary source of these four species. If these compounds were present in the dust particles at the source, we would expect their peak area ratios to remain constant as long as the dust source regions were not changing over short time periods. Clear temporal changes in the relative amounts of the secondary species associated with the dust are evident. Similar changes were also observed for these same species in the bulk mass concentration measurements of the dust-impacted air masses reported by Bates et al. (2004) and Quinn et al. (2004).

The presence of chloride in dust not due to mixtures with sea salt has only recently been reported (Zhang and Iwasaka, 2001). A very large increase in the chloride area ratio in dust (Fig. 2) was observed during the dust front's arrival, along with an increase in the total chloride mass concentration by a factor of nine (Arimoto et al., 2006; Bates et al., 2004). As discussed in detail by Sullivan et al. $(2006)^{1}$, the availability of $\mathrm{HCl}(\mathrm{g})$ for reaction with the mineral dust was likely strongly influenced by the release of $\mathrm{SO}_{2}(\mathrm{~g})$ from the nearby Miyakejima volcano. The sea salt particles in the prefrontal air mass were highly aged and resulted in a depletion of $77 \pm 12 \%$ of the total chloride in the sea salt (Bates et al., 2004; Sullivan et al., 2006) ${ }^{1}$. Thus, there were likely elevated levels of $\mathrm{HCl}(\mathrm{g})$ in the marine boundary layer just prior to the dust front's arrival. This liberated $\mathrm{HCl}(\mathrm{g})$ then mixed with the incoming dust front as it subsided while there were depleted levels of $\mathrm{HNO}_{3}(\mathrm{~g})$ and $\mathrm{SO}_{2} / \mathrm{H}_{2} \mathrm{SO}_{4}(\mathrm{~g})$, due to their prior reaction with sea salt, permitting substantial chloride

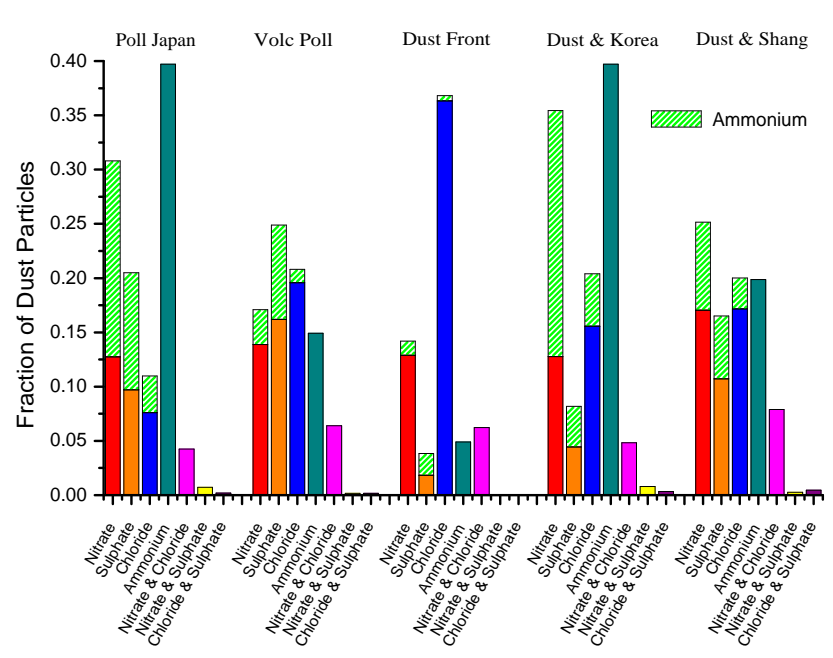

Fig. 4. Fractions of mineral dust particles internally mixed with major secondary inorganic species in different air masses. A peak area $>5000$ was used to define dust particles as mixed with chloride, nitrate, and sulphate, and a peak area $>1000$ for ammonium. Dust particles mixed with sea salt have been excluded. The hatched portion of the column represents the fraction of dust particles mixed with a particular secondary acid that also contained ammonium (peak area $>1000$ ).

uptake onto the mineral dust. Figures 2 and 3 clearly show an increase in the amount of chloride in dust and a simultaneous decrease in the amount of nitrate and sulphate in dust during the Dust Front period. Had nitrate and/or sulphate formed on the dust particles during the dust front, this would have displaced much of the chloride to the gas-phase, or prevented its uptake in the first place. Thus, we hypothesize that the significant uptake of chloride by dust during the dust front occurred due to both the reduced mixing ratios of $\mathrm{NO}_{\mathrm{y}}$ and $\mathrm{SO}_{\mathrm{x}}$, caused by their prior reaction with sea salt in the prefrontal air mass, and the subsequent release of $\mathrm{HCl}(\mathrm{g})$ from the highly aged sea salt particles (Sullivan et al., 2006) ${ }^{1}$.

In Fig. $3 b$ the hourly counts of dust mixed with one of the secondary species are plotted versus the total hourly dust counts measured by ATOFMS. Sulphate-dust has a very weak dependence on the total dust counts while nitrate-dust and chloride-dust have much stronger correlations over the DOY 98-105 time period. Thus, the mixing of dust with sulphate does not appear to be controlled by the total dust concentrations available, while the number of dust particles mixed with nitrate or chloride increases with increasing total dust concentrations. An explanation for this behaviour is that sulphate becomes preferentially mixed with dust. This could be the result of dust reacting with $\mathrm{SO}_{2} / \mathrm{H}_{2} \mathrm{SO}_{4}$ more efficiently, and/or because the dust plume encounters elevated sulphate precursors before encountering nitrate and chloride precursors. If dust mixes with sulphate first and becomes acidified then, in general, nitrate and chloride will only be able to become significantly mixed with dust if there is an 


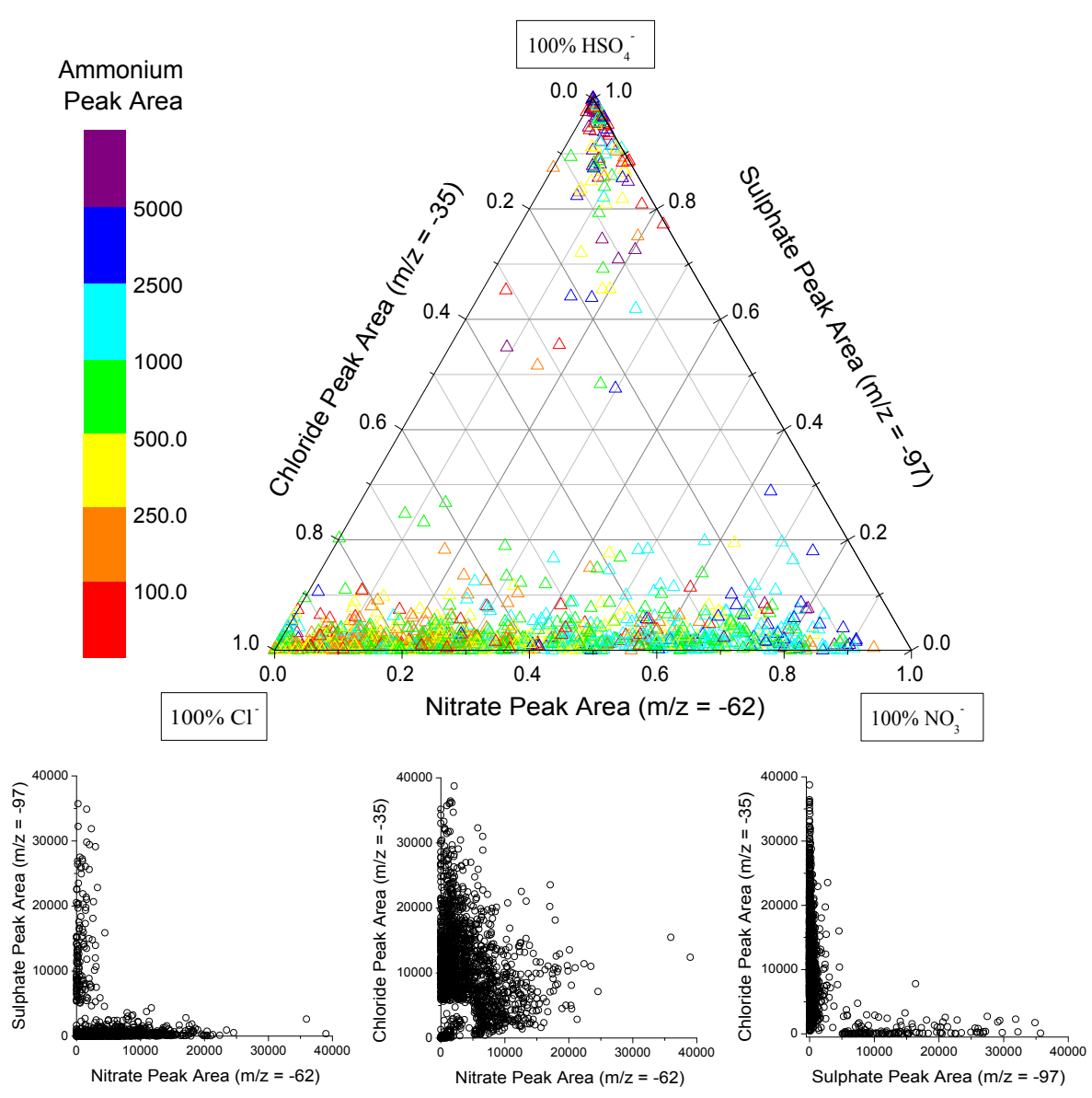

Fig. 5a. The ternary plot (top) shows the relative distribution of peak areas for secondary chloride, nitrate, and sulphate in filtered mineral dust particles defined as "mixed" with either of the three acid products and detected during the Dust Front period (DOY 101-101.3). Each point is produced from a single dust particle's mass spectrum, 1768 in total are plotted. The symbol colour corresponds to the absolute peak area of ammonium for each dust particle. The scatter plots (below) for pairs of secondary acid products are taken from the same data set and show the same trends as the ternary plot but on an absolute peak area scale.

abundance of additional, mostly unreacted dust surface area available for reaction with nitrate and chloride precursors. There would therefore be a dependence on total dust loadings for nitrate- and chloride-dust, as shown in Fig. 3b. The degree to which the mineral dust becomes internally mixed with a particular acid is likely predominantly controlled by the history of the air mass.

\subsection{Mixing state of secondary acids in mineral dust}

Nitrate- and sulphate-dust together accounted for 13754 particles from DOY $98-105$, yet only $142(1.03 \%)$ of these dust particles satisfied the peak area $>5000$ criterion for both ${ }^{62}\left[\mathrm{NO}_{3}\right]^{-}$and ${ }^{97}\left[\mathrm{HSO}_{4}\right]^{-}$. Thus, significant amounts of both nitrate and sulphate did not accumulate on the same mineral dust particles. Similarly, only 98 out of $12272(0.80 \%)$ chloride-dust and sulphate-dust particles satisfied the peak area criteria for both ${ }^{35} \mathrm{Cl}^{-}$and ${ }^{97} \mathrm{HSO}_{4}{ }^{-}$, demonstrating that secondary chloride and sulphate were also externally mixed in the mineral dust. Nitrate and chloride, however, were present in the same mineral dust particles to a large extent; $14.8 \%$ of chloride-dust and nitrate-dust particles had peak areas $>5000$ for both ${ }^{35} \mathrm{Cl}^{-}$and ${ }^{62} \mathrm{NO}_{3}{ }^{-}$. Recall that dust mixed with sea salt was excluded from this analysis and thus cannot account for this result. Further mixing state statistics for prefrontal and postfrontal air masses are provided in Fig. 4, demonstrating the very low fractions of dust particles that contained significant amounts of both sulphate and nitrate or chloride in several different air masses.

The relative amounts of the three secondary species on all reacted dust particles during two time periods are shown in Fig. 5. In the ternary plot, a dust particle containing primarily sulphate would appear at the top vertex, primarily nitrate at the right vertex, and primarily chloride at the left vertex. For both the Dust Front period (Fig. 5a) and the pre-frontal Polluted Volcano period (Fig. 5b), two broad groups of particles are evident in the ternary plots. The majority of particles lie along the bottom nitrate-chloride axis, indicating a 
wide range of internal mixing between nitrate and chloride in individual dust particles. A smaller but still substantial group of particles is found at the top sulphate vertex, indicating that these dust particles contain primarily sulphate and relatively little nitrate or chloride. The lack of a significant number of particles lying along the sulphate-chloride or sulphate-nitrate axes, or found in the centre of the ternary plot, further demonstrates that sulphate in aged mineral dust particles is externally mixed from both nitrate and chloride. This is true for dust particles that contain significant amounts of secondary acid products. Nitrate and sulphate are found in the same dust particle but with peak areas much lower than the 5000 threshold, representing less chemically aged dust. The colour of each point reflects that dust particle's ammonium absolute peak area. The largest ammonium signals were found in dust particles also containing nitrate or sulphate while chloride-dust particles had lower but still significant amounts of ammonium. The ternary plots of dust particles detected during the Polluted Volcano and Dust Front periods share these general features but there are more particles from the sulphate-only group in the Polluted Volcano period and more in the nitrate-chloride group during the Dust Front period. This agrees with the temporal changes displayed in Figs. 2 and 3 that show a larger fraction of sulphate-dust before the dust front and a larger nitrate-dust and chloride-dust fraction during the dust storm. The PMEL filter mass measurements show similar temporal behaviour for these species (Bates et al., 2004).

This segregation of sulphate from nitrate and chloride is further demonstrated by the scatter plots (bottom) in Fig. 5a for the Dust Front period. The ternary plots show the relative partitioning of the absolute peak area signals for dust particles between the three major secondary acid peaks (with areas $>5000$ ). The scatter plots, however, show the absolute areas for a set of two secondary acids for the same set of reacted dust particles used to generate the ternary plot. The large number of particles found along either axis in the sulphatenitrate and sulphate-chloride scatter plots agrees with the segregation of sulphate from nitrate and chloride shown in the ternary plot. The large number of particles found near the centre of the nitrate-chloride scatter plot, however, further supports the substantial and variable internal mixing of these two secondary acids in the mineral dust. The reduced number of particles around the origin is caused by the peak area $>5000$ criterion for ${ }^{35} \mathrm{Cl}^{-},{ }^{62} \mathrm{NO}_{3}{ }^{-}$, or ${ }^{97} \mathrm{HSO}_{4}{ }^{-}$. Very similar results were also found for the Polluted Volcano period (not shown).

\subsection{Uptake of ammonia by acidified dust}

In general, mineral dust shifts ammonia from the particle to gas phase by changing the aerosol from a cation- to anionlimited state due to the presence of alkaline species such as calcium carbonate (Song and Carmichael, 1999; Tang et al., 2004b). Mineral dust that has accumulated secondary

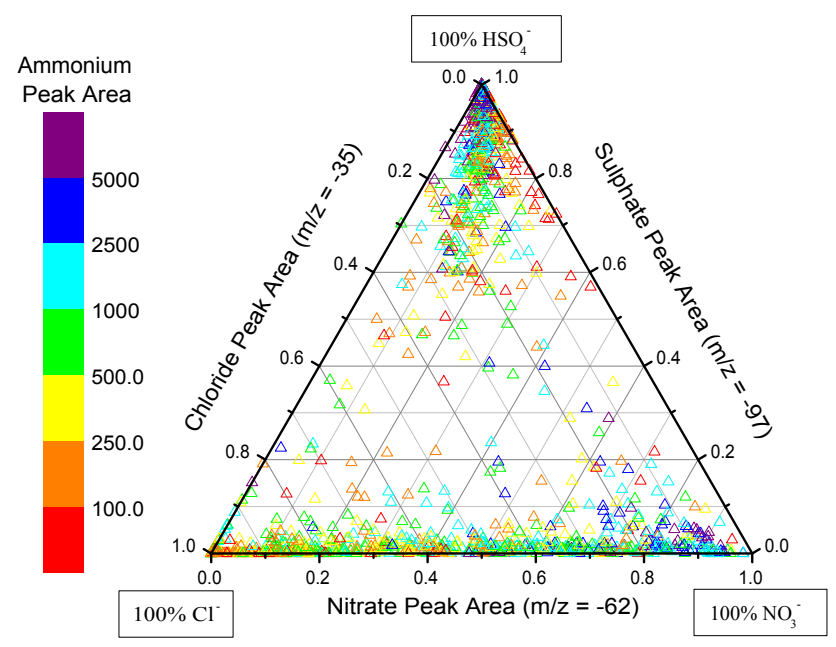

Fig. 5b. As for Fig. 5a above but for dust particles detected during the Polluted Volcano period (DOY 99.3-100.5). Each point is produced from a single dust particle's mass spectrum, 1361 in total are plotted.

acids can be a sink for ammonia, as a result of either direct uptake from the gas-phase, coagulation with ammonium sulphate/nitrate-containing particles (Mori et al., 1998), or heterogeneous nucleation (Korhonen et al., 2003). The acid can be present after reacting with and neutralising the alkaline carbonates in the dust, or also by physisorption to the dust surface without chemical reaction. In the case of physisorption, ammonia can react with the acid on the surface without the prior consumption of alkalinity. The contributions of both processes should be explored, though likely reaction with alkaline carbonates accelerates the uptake of acids over simple physisorption.

The presence of ammonium nitrate and/or ammonium sulphate in individual mineral dust particles is demonstrated in Fig. 6. The large cluster of particles lying along the ammonium-sulphate axis on the left indicates the presence of ammonium sulphate in mineral dust particles, while the smaller cluster of particles along the bottom ammoniumnitrate axis represents ammonium nitrate in dust. The fact that these particles appear primarily along one of these two axes indicates that the ammonium sulphate- or ammonium nitrate-dust particles do not also contain a significant nitrate or sulphate signal, respectively. This is expected based on the external mixing of nitrate and sulphate in dust presented above. The much larger spread in the ammonium sulphate dust particles along the ammonium-sulphate axis compared to the ammonium nitrate cluster may be due to the variable $\mathrm{NH}_{4}: \mathrm{SO}_{4}$ molar ratio caused by partitioning between $\left(\mathrm{NH}_{4}\right)_{2} \mathrm{SO}_{4}, \mathrm{NH}_{4} \mathrm{HSO}_{4}$, and $\mathrm{H}_{2} \mathrm{SO}_{4}$.

Dust mixed with ammonium was queried using a peak area $>1000$ for ${ }^{18}\left[\mathrm{NH}_{4}\right]^{+}$criterion. Further details on this analysis are provided in the Appendix. Since a particle should first contain some acidic species in order for ammonia to parti- 


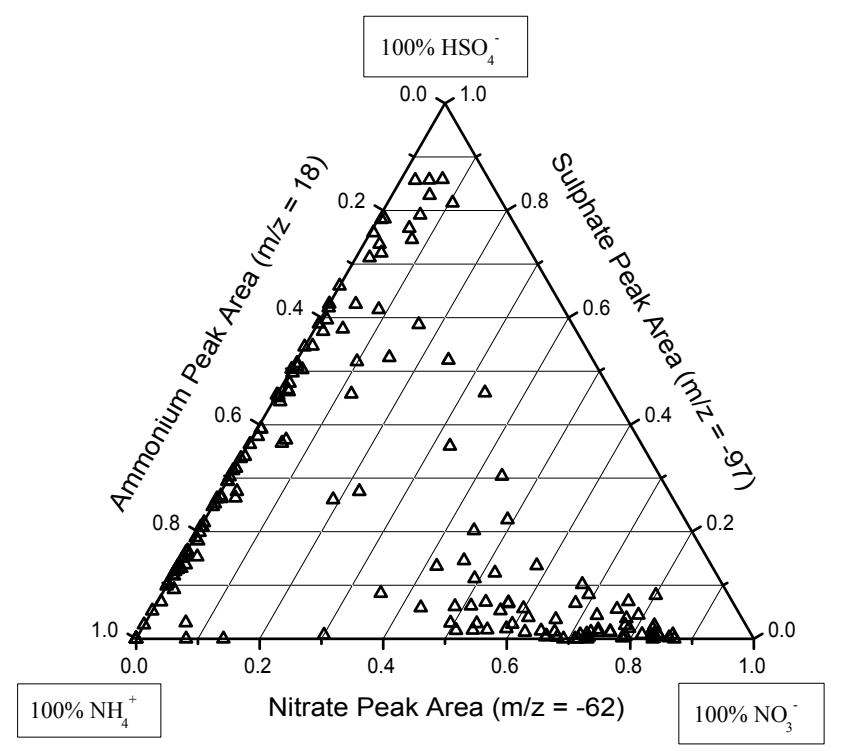

Fig. 6. Relative distribution of absolute peak areas for nitrate, sulphate, and ammonium in nitrate-dust or sulphate-dust satisfying a peak area for $m / z 18>1000$, detected during the Polluted Volcano period. 364 dust particles are displayed.

tion to it, we would predict that the number of dust particles that contained ammonium would increase when the number of particles containing nitrate or sulphate increased. This would also be true if the mixing of dust with ammonium was caused by coagulation with or heterogeneous nucleation by ammonium nitrate/sulphate particles. Figure 7 shows how the fraction of reacted dust particles that contained ammonium tracked the temporal changes in the fractions of dust particles mixed with either nitrate or sulphate. The linear correlations between the hourly counts of dust that contained ammonium nitrate/sulphate and those that were mixed with nitrate/sulphate showed excellent agreement with $R^{2}=0.808$ and 0.814 , respectively (Fig. 7 insets). This is an impressive degree of correlation considering that these queries were performed on all reacted dust particles, regardless of mineralogy, for seven days of ambient sampling which included several changes in the air mass source regions. The slopes of these correlations indicate the average fraction of nitratedust or sulphate-dust particles which also contained ammonium over this time period were $43 \%$ and $32 \%$, respectively. More detailed mixing state statistics for dust containing ammonium and secondary acids are given in Fig. 4.

We are not able to directly determine the degree to which available alkalinity in the dust has been neutralised by the secondary acids. However, we do find that ammonium was only in dust particles that also contained secondary acids in the form of nitrate, sulphate or, to a lesser extent, chloride (see Appendix for details). Taking the sum of the nitrate $(\mathrm{m} / z=-62 / 27)$ and sulphate $(\mathrm{m} / z=-97 / 27)$ hourly peak area ratios as a measure of the available acid in the dust and plot- ting this versus ammonium $(m / z=18 / 27)$ in Fig. 8 reveals a strong temporal trend between the amount of acid in the dust and the amount of ammonium, as expected. Note the strong anti-correlation of ammonium and the two other acids with chloride $(m / z=-35 / 27)$ in the dust, particularly on DOY 101. However, on DOY 104 the peak area ratios for chloride, and the two acids all stabilize. The degree of correlation between the hourly peak area ratios for nitrate + sulphate, and ammonium has a $\mathrm{R}^{2}=0.574$.

In the troposphere, ammonium sulphate is the most stable and thus preferred ammonium salt, followed by ammonium nitrate. Ammonium chloride, while the least preferred, is also a realistic ammonium salt in the troposphere. Dust containing ammonium chloride was detected during two distinct time periods (DOY 108.88-102.38 and 103.0-105.0, see Appendix for details). Thus, the amount of ammonium in dust should track the amount of chloride, in addition to sulphate and nitrate on dust. This should be especially true when the stronger sulphuric and nitric acids are not available to neutralise ammonia first, as was the case for the Dust Front period. If chloride is also included in the sum of the peak area ratios (Fig. 8), the $\mathrm{R}^{2}$ is greatly improved from 0.574 to 0.881 . This result was found despite the strong anticorrelation between the peak area ratio of chloride and ammonium. This could reflect the fact that ammonium chloridedust was only detected in two periods and at low concentrations, the first of which occurred when both sulphate-dust and nitrate-dust were greatly reduced. Thus, by including chloride, this time period of ammonium mixed with dust that would not be explained by sulphate or nitrate was captured. The overall anti-correlation of chloride and ammonium on dust may simply be a reflection of an anti-correlation of $\mathrm{HCl}(\mathrm{g})$ and $\mathrm{NH}_{3}(\mathrm{~g})$ mixing ratios, as the two likely have very different sources for this area. It does not necessarily reflect an inefficient process for ammonia to react with dust acidified by $\mathrm{HCl}$.

The internal mixing of $\left(\mathrm{NH}_{4}\right)_{2} \mathrm{SO}_{4}, \mathrm{NH}_{4} \mathrm{NO}_{3}$, and $\mathrm{NH}_{4} \mathrm{Cl}$ with dust is a significant finding that has previously been reported from ATOFMS ambient measurements in Riverside, California (Noble and Prather, 1996), but not for dust storm events. Heterogeneous nucleation of $\left(\mathrm{NH}_{4}\right)_{2} \mathrm{SO}_{4}$ on dust can produce ammonium sulphate coatings around dust and suppress the growth of ammonium sulphate particles to detectable sizes (Korhonen et al., 2003). Several researchers have frequently stated that ammonium sulphate measured in submicron particles during dust storms are due to ammonium sulphate particles externally mixed from dust (Jordan et al., 2003; Mori et al., 2003; Song et al., 2005; Tang et al., 2004b). We have clearly demonstrated that ammonium sulphate was internally mixed with dust particles during ACE-Asia, particularly in the submicron dust (Fig. 6). Thus, the assumption of externally mixed ammonium sulphate and dust particles during ACE-Asia at sea level should be re-evaluated. In the future, single particle measurements can be used to unambiguously determine the exact aerosol mixing state. 

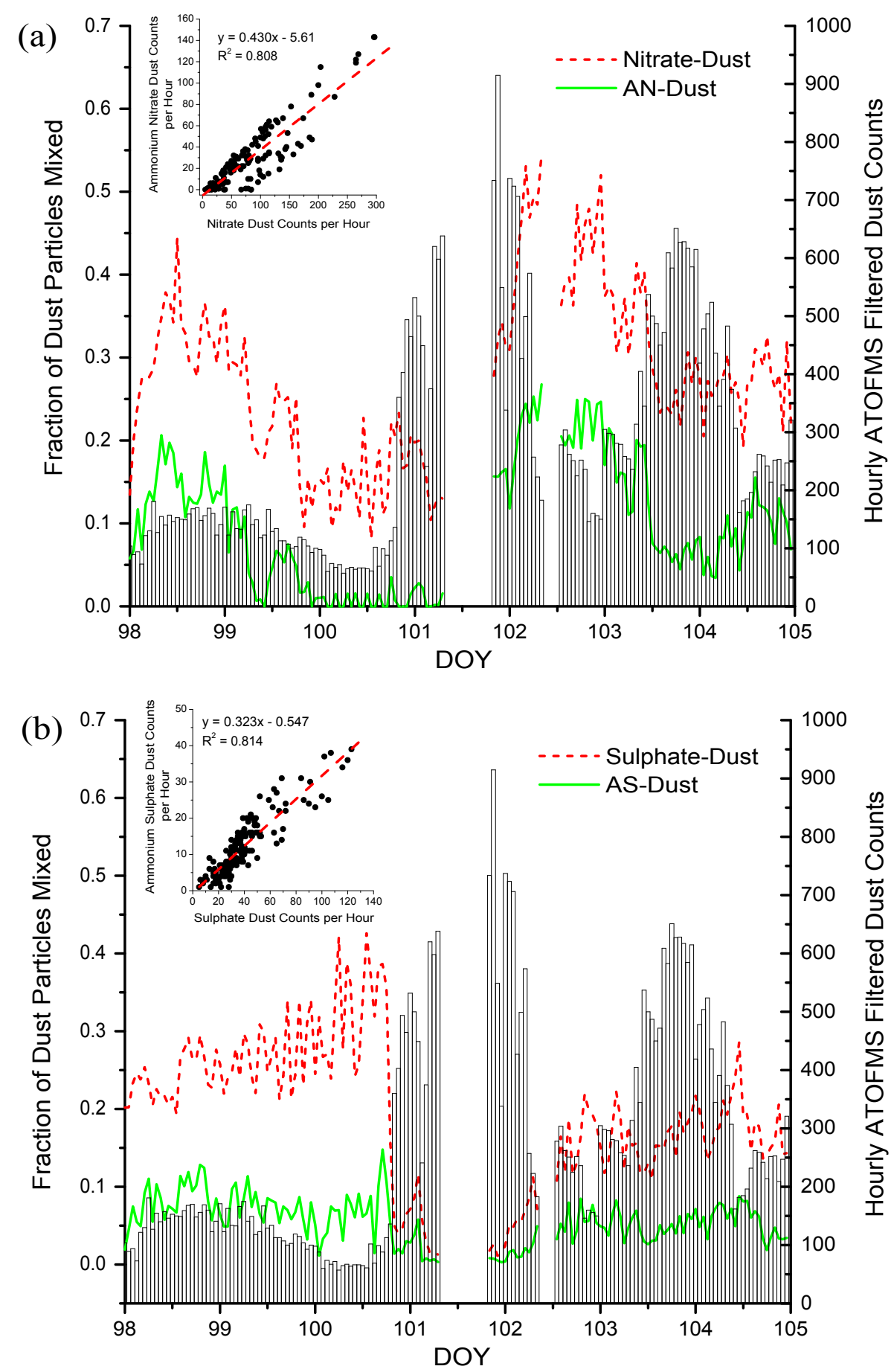

Fig. 7. The fractions of filtered dust particles (lines) classified as mixed with (a) nitrate or ammonium nitrate (AN); (b) sulphate or ammonium sulphate (AS); and the total hourly filtered dust counts (bars). Scatter plots (insets) show the correlation between hourly counts of nitrate/sulphate dust and ammonium nitrate/sulphate dust. The slope of the linear fit indicates the average hourly fraction of nitrate- or sulphate-dust that was also mixed with ammonium.

\subsection{Effect of dust mineralogy on chemical processing}

The role that dust particle mineralogy plays in its interactions with secondary acids and their precursors was investi- gated by comparing dust particles with high amounts of $\mathrm{Ca}$ to dust with high amounts of Al. These types broadly represent dust particles rich in calcite or aluminosilicates, respectively. This was achieved by searching within the filtered 

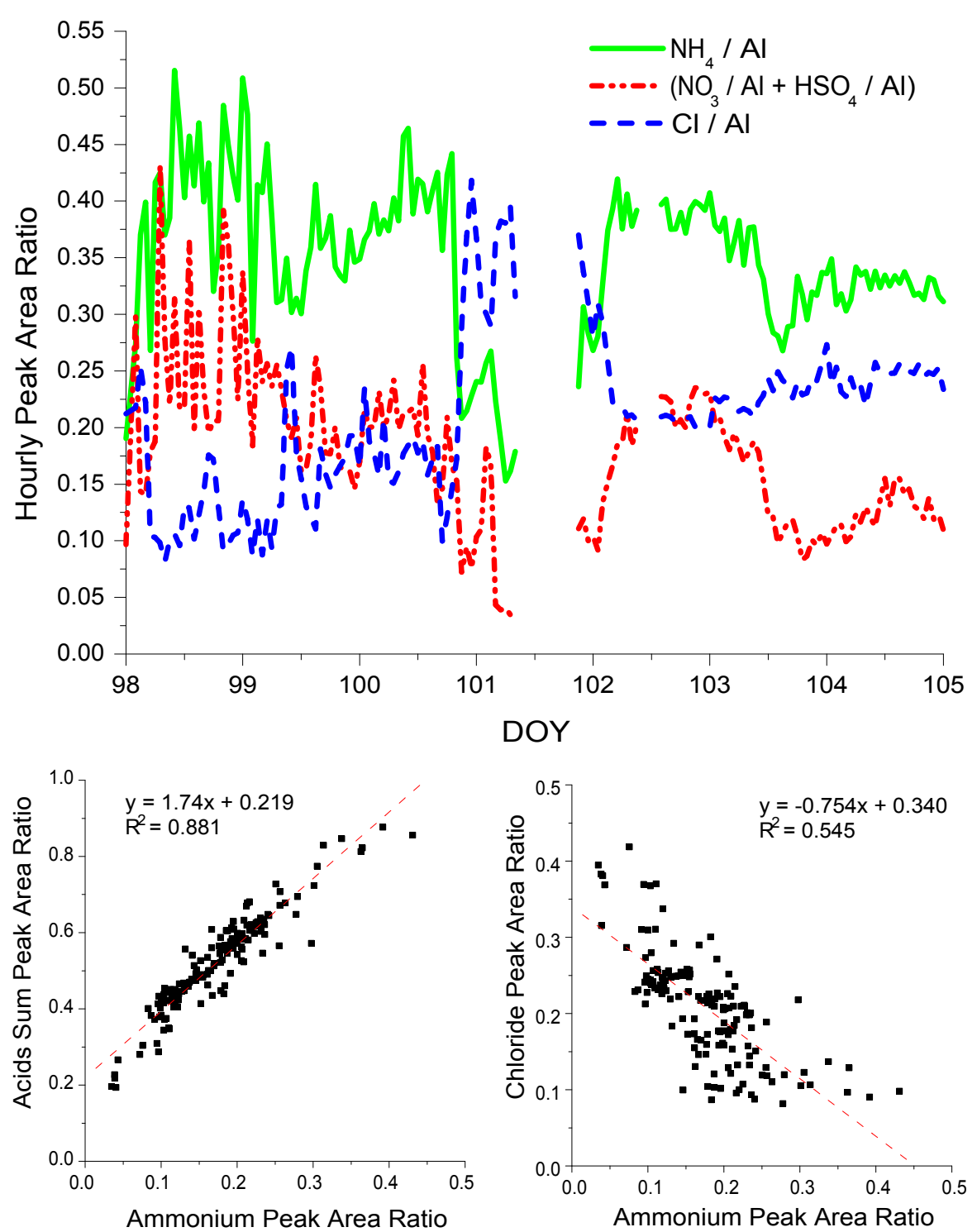

Fig. 8. Correlation between ammonium and acids in dust. Top: Hourly peak area ratios for ammonium (18/27), chloride (-35/27) and the sum of nitrate $(-62 / 27)$ plus sulphate $(-97 / 27)$ for all filtered dust particles from DOY 98-105. Bottom: Scatter plots of the correlation between ammonium and sum of chloride + nitrate + sulphate hourly peak area ratios for this time period (left), the hourly peak area ratios of chloride and ammonium (right), and the corresponding least-squares linear fits.

dust for particles with a relative peak area $>10 \%$ for either ${ }^{27} \mathrm{Al}^{+}$or ${ }^{40} \mathrm{Ca}^{+}$. Together these two types of dust account for $55.2 \pm 5.7 \%$ of the total filtered dust counts. Clear differences between these two types of dust are shown in the temporal changes of the hourly peak area ratios for the three major secondary acid reaction products in Fig. 9. Most notable is a large spike in the sulphate area ratio at DOY 100.5 in the high-Al dust that does not occur in the high-Ca dust. The sulphate peak area ratio also increases from DOY 103.5105 in the high-Al dust but remains mostly unchanged in the high-Ca dust. There are also noticeable differences in the increases in the chloride area ratio from DOY 101-102 for the two types of dust. The majority of chloride uptake during the Dust Front period, beginning on DOY 100.8, took place on the high-Ca dust particles, suggesting reaction with calcite in the dust.

These results imply that sulphate is more strongly associated with aluminosilicate-rich dust particles while nitrate and chloride are more associated with calcite-rich dust. Figure 10 provides further evidence for this mineralogy dependence. The ternary plot displays the relative distribution of three major dust mineral components: aluminium, calcium, and iron. The ${ }^{54} \mathrm{Fe}$ isotope was selected for iron to avoid interference from ${ }^{56}[\mathrm{CaO}]^{+}$. Reacted dust particles detected during the 

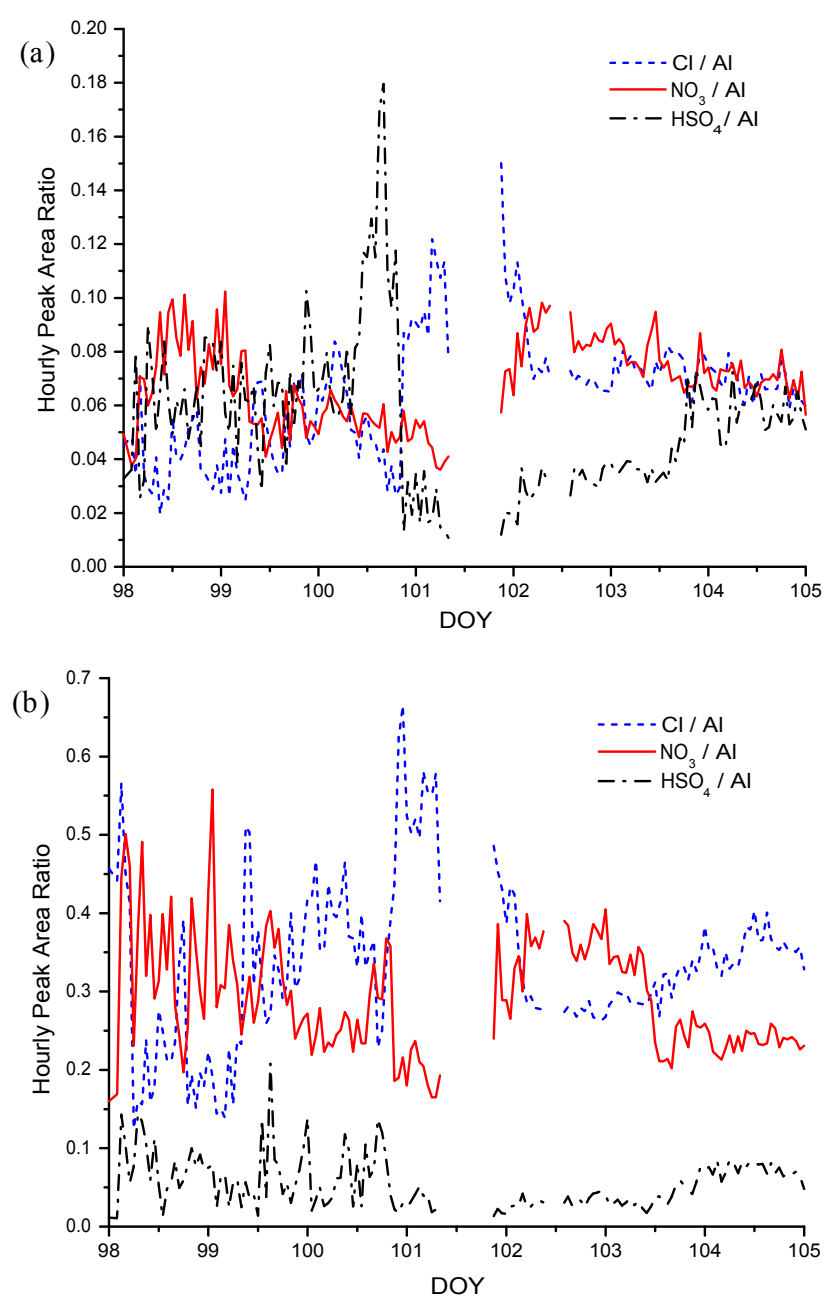

Fig. 9. Hourly peak area ratios of the three major secondary acid reaction products: chloride, nitrate and sulphate, for filtered dust particles with large ion signals for $\mathrm{Al}$ (a) or $\mathrm{Ca}(\mathbf{b})$.

Dust \& Shanghai period are displayed in both Figs. 10a and b. In Fig. 10a, the symbol colour corresponds to the sulphate absolute peak area while in Fig. 10b, the colour corresponds to the nitrate absolute peak area. Only dust particles containing relatively large amounts of nitrate or sulphate (peak area $>5000$ ) are displayed. These two figures show dramatically different mixing behaviour for nitrate versus sulphate and are virtually complete opposites of one and other. This reflects the segregation of large amounts of nitrate and sulphate in dust particles, as discussed above. The sulphaterich dust particles predominantly lie near the aluminium vertex and extend towards the iron vertex, indicating an association with aluminosilicate-dust particles and their associated enriched iron content (Jickells and Spokes, 2001). The nitrate-dust particles are mostly located towards the calcium vertex, being associated with calcite- and dolomite-rich dust. An analogous ternary plot using the chloride peak area (not shown) displays very similar behaviour to the nitrate ternary
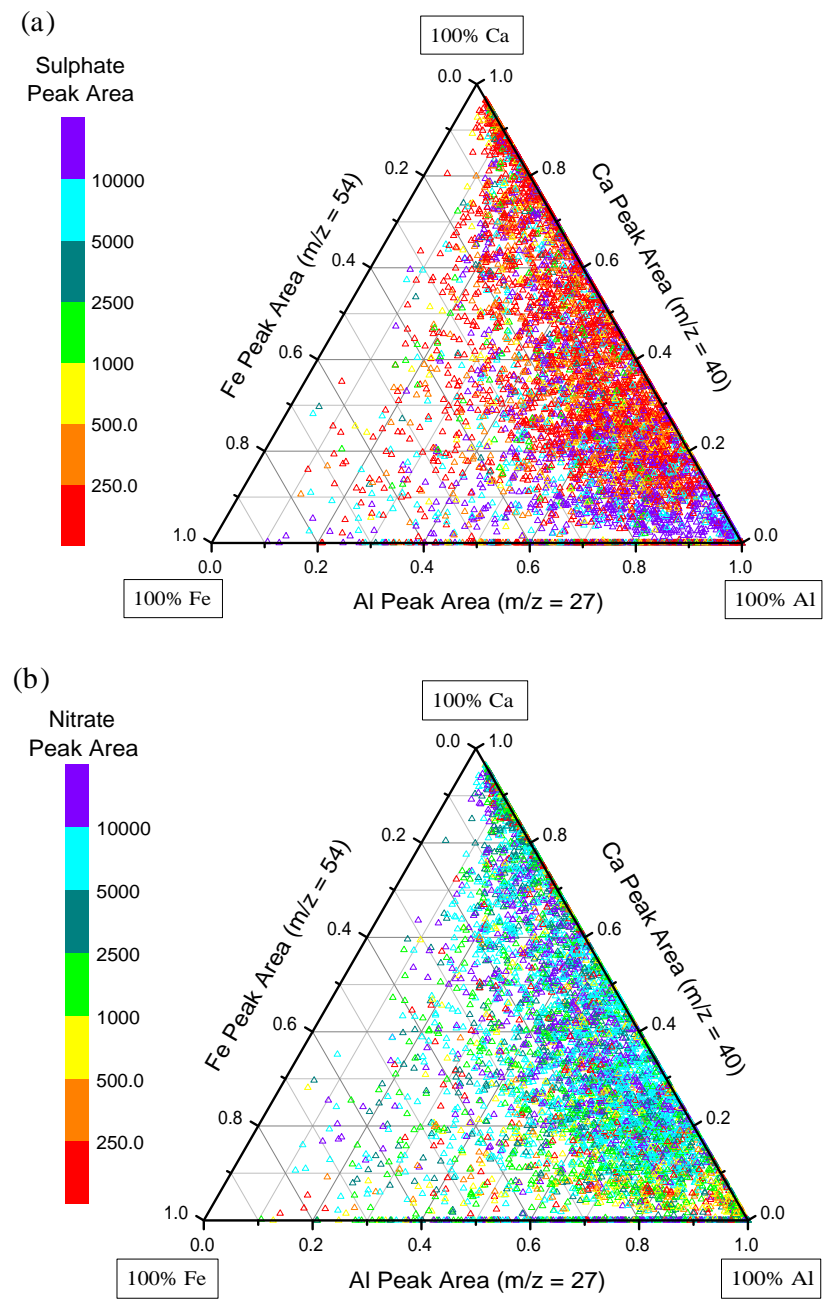

Fig. 10. Relative distribution of peak areas for three major mineral components, $\mathrm{Fe}, \mathrm{Ca}$, and $\mathrm{Al}$, for reacted dust particles detected during the Dust \& Shanghai period. The same 5812 dust particles are displayed in both figures with the symbol colour corresponding to the sulphate absolute peak area (a), or the nitrate absolute peak area (b).

plot (Fig. 10b), with the largest chloride peak areas being found on Ca-rich dust particles, while Al-rich particles contain much lower chloride signals. The processes that cause this behaviour are discussed below.

The carbonate portion of Asian mineral dust is typically considered to be the principle component controlling the uptake of acidic vapours by dust due to its alkalinity (Song and Carmichael, 1999; Song and Carmichael, 2001; Tang et al., 2004b). Both $\mathrm{HNO}_{3}$ and $\mathrm{HCl}$ are mineral acids with an acidic proton that can be readily neutralised upon reaction with alkaline species such as carbonate. $\mathrm{SO}_{2}$ however, is an acid anhydride and does not contain acidic protons until it is hydrated and oxidized to $\mathrm{S}(\mathrm{VI})$. The strong association of nitrate and chloride with calcium-rich dust could be due to the ability of $\mathrm{HNO}_{3}, \mathrm{HCl}$ and other precursors to react 

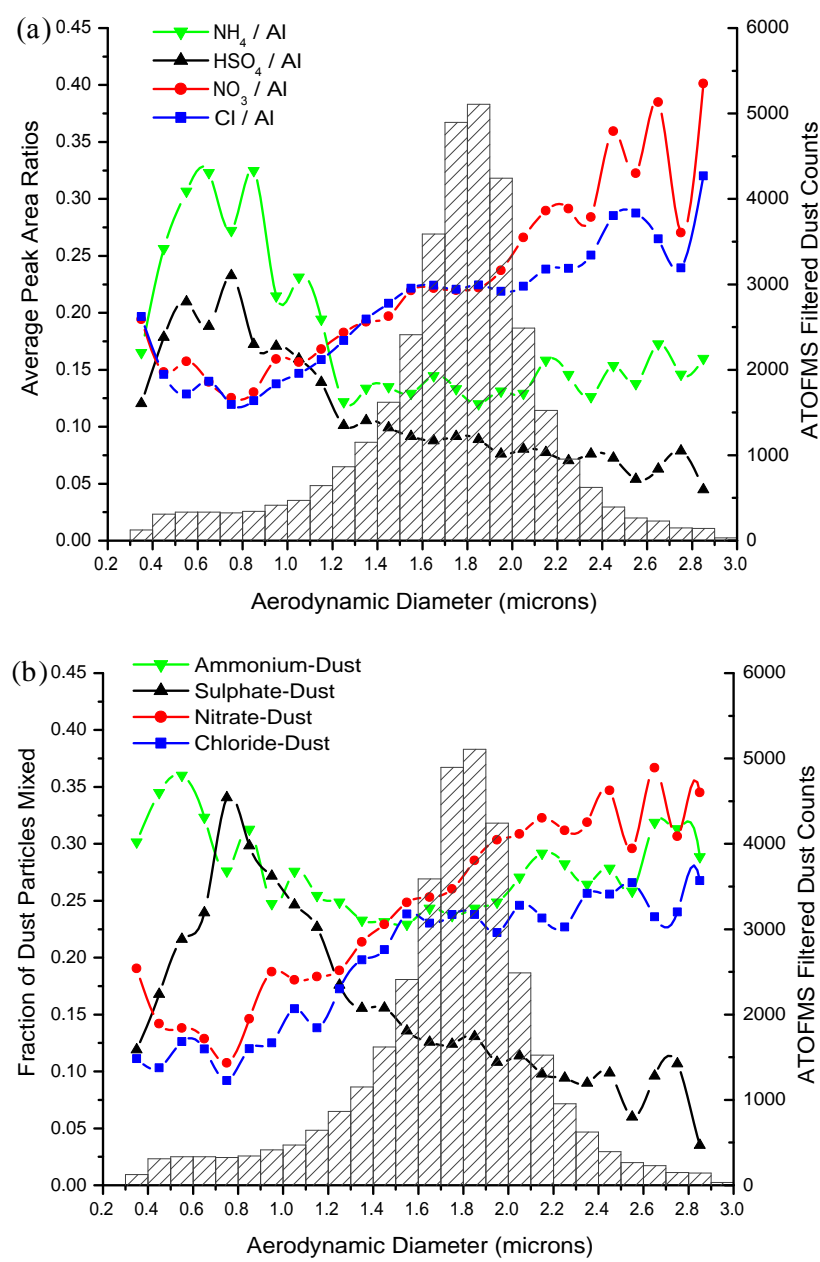

Fig. 11. Size distributions of secondary species in mineral dust particles. (a) Average single-particle peak area ratios (lines) for four major secondary species from all filtered dust particles detected from DOY 98-105. (b) Fraction of filtered dust particles (lines) classified as mixed with one of the four major secondary species. The size distribution of the set of particles used to generate both figures is also displayed (columns) and reflects the inlet efficiency of the ATOFMS, and not the actual size distribution of the aerosol population.

with carbonates through simple acid-base chemistry. $\mathrm{SO}_{2}$, not initially containing any acidic protons, is unable to react with calcium carbonates in this direct manner. This would explain why sulphate is not enriched in calcium-rich dust. Since our data suggest that sulphate accumulates in the dust first, it appears sulphate will react with the mineral component for which it has the highest affinity. We propose that the association of sulphate with $\mathrm{Al}$ - and $\mathrm{Fe}$-rich dust is due to the iron-catalyzed oxidation of $\mathrm{SO}_{2}$ to $\mathrm{H}_{2} \mathrm{SO}_{4}$ (Brandt and Vaneldik, 1995; Qi et al., 2006; Rani et al., 1992; Yermakov and Purmal, 2003). The majority of the oxidation by this process is thought to occur in the aqueous phase containing dissolved metal ions (i.e. a homogeneous reaction), but the role of surface-catalyzed heterogeneous reactions involving metals may also play an important role (Brandt and Vaneldik, 1995; Rani et al., 1992). The solubility of the metal ions is a key factor controlled by the aerosol's $\mathrm{pH}$ and the presence of organic compounds that could chelate the metals. The solubility of iron in dust aerosols is an important but poorly understood factor at present (Jickells et al., 2005; Luo et al., 2005). The rate of this reaction is accelerated at higher $\mathrm{pH}$ and thus this sulphate formation pathway is self-quenching. The alkaline nature of Asian mineral dust could enhance the role of iron in the oxidation of sulphur by buffering the $\mathrm{pH}$ and increasing this pathway's reaction rate compared to other major pathways such as oxidation by $\mathrm{H}_{2} \mathrm{O}_{2}$. Relativity humidity has been found to be an important factor for the uptake of acids by dust in both lab and recent field studies (AlHosney and Grassian, 2005; Goodman et al., 2001; Krueger et al., 2003; Laskin et al., 2005; Matsuki et al., 2005b; Ullerstam et al., 2002), however our data set does not allow us to directly investigate this important issue.

\subsection{Mechanism of secondary acid uptake: size dependence}

The distribution of secondary species as a function of dust particle size provides important insights into the mechanisms for the accumulation of acids in dust. The mechanism that is outlined here is based on that of Bassett and Seinfeld (1984) and Song and Carmichael (1999). In general, the accumulation of sulphate by particles through reaction with $\mathrm{SO}_{2} / \mathrm{H}_{2} \mathrm{SO}_{4}$ is diffusion limited. Thus, it occurs preferentially in the particle size mode with the greatest surface area, which is typically the accumulation mode $\left(D_{a}=0.1-1.0 \mu \mathrm{m}\right)$. As sulphuric acid is essentially non-volatile and a stronger acid than both nitric or hydrochloric acid, the accumulation of sulphuric acid in a particle will prevent additional uptake of $\mathrm{HCl}, \mathrm{HNO}_{3}, \mathrm{NO}_{2}$, etc. These gases will instead react with the less-acidic supermicron dust that represents a larger alkaline sink by mass for these acids. The accumulation of sulphuric acid in submicron dust will also displace any preexisting nitrate or chloride back to the gas-phase as these are weaker acids and more volatile than $\mathrm{H}_{2} \mathrm{SO}_{4}$. Nitric acid and hydrochloric acid in the gas-phase can then re-partition to supermicron dust particles that have not already been acidified (Song and Carmichael, 2001). Thus, the irreversible uptake of $\mathrm{SO}_{2}$ and $\mathrm{H}_{2} \mathrm{SO}_{4}$ is kinetically limited while the uptake of the more-volatile $\mathrm{HCl}$ and $\mathrm{HNO}_{3}$ is thermodynamically controlled. Therefore, sulphate will accumulate in submicron dust while nitrate and chloride will accumulate in supermicron dust particles. The uptake of ammonia is typically determined by the preceding $\mathrm{SO}_{2} / \mathrm{H}_{2} \mathrm{SO}_{4}$ uptake, and thus ammonium predominantly accumulates in submicron dust.

Evidence for this uptake mechanism occurring in the aged mineral dust detected during ACE-Asia is presented by the distribution of the peak area ratios for these secondary species as a function of particle size in Fig. 11a. The average peak area ratios for sulphate and ammonium clearly peak 
in the submicron filtered dust particles. Nitrate and chloride both peak in the supermicron dust particle mode. Despite the high loading of supermicron dust during the dust front, the largest aerosol surface area mode was still in the accumulation mode (Bates et al., 2004; Quinn et al., 2004). Similar results are shown in Fig. 11b, this time plotting the fraction of filtered dust particles previously classified as mixed with chloride, nitrate, sulphate (peak area $>5000$ ), or ammonium (peak area $>1000$ ) as a function of size. Again, sulphate-dust peaks in the submicron mode while nitrate- and chloride-dust peak in the supermicron. Ammonium-dust has two modes, the largest in the submicron mode along with sulphate-dust and a smaller one in the supermicron mode along with nitrate and chloride-dust. Taken together, these size plots indicate that ammonium accumulates in both the submicron sulphate-dust and the supermicron nitrate/chloride-dust, but the relative amount of ammonium per dust particle is greater in the submicron sulphate-dust mode.

The results suggest that the submicron dust particles were very acidic due to mixing with sulphuric acid early during transport. This prevented the substantial mixing of nitrate and chloride in the submicron dust particles when the dust plume later encountered elevated $\mathrm{NO}_{\mathrm{y}}$ and $\mathrm{HCl}$. This also suggests that there was not enough ammonia to neutralise all of the sulphuric acid in the dust. The bulk mass concentration of ammonium was relatively constant from DOY 98-105 while that of nitrate and sulphate varied significantly and were elevated in the post-frontal dust air masses, exceeding ammonium (Bates et al., 2004). The internal mixing of nitrate and chloride (Fig. 5) is a result of the greater alkaline mass in the supermicron dust that can neutralize both acids and allow them to exist internally mixed to some degree in the same dust particle. The volatile nature of these two inorganic species allows them both to be displaced to the gas-phase, if displacement is occurring, and then re-partition back to the supermicron dust particles where they are less volatile.

Similar size-distributions of secondary species in Asian mineral dust have been reported previously from the analysis of collected filter samples and in modeling studies (Bates et al., 2004; Mori et al., 2003; Nishikawa et al., 1991; Ooki and Uematsu, 2005; Tang et al., 2004b; Wu and Okada, 1994; Zhang et al., 2000). However, our results are the first to show the size distribution of secondary species exclusively for individual aged mineral dust particles. We also have the ability to exclude the influence of internally mixed dust and sea salt particles. The $0.10 \mu \mathrm{m}$ size resolution provided by the ATOFMS measurements is another significant advantage over filter-based methods. Together these factors result in a unique and important set of results that directly confirm aerosol model predictions of mineral dust aging mechanisms.

\subsection{Segregation of sulphate from nitrate and chloride}

To the best of our knowledge, this is the first report of the segregation of sulphate from nitrate and chloride in individual mineral dust particles that have experienced extensive atmospheric aging and transport (Figs. 5 and 10), along with the preliminary results summarized in Arimoto et al. (2006). Murphy and Thomson (1997) reported the external mixture of chloride and sulphate in individual ambient particles (not limited to dust) detected at Idaho Hill and also found that sulphate and nitrate were usually, but not always, found in separate particles. Zhang et al. (2000) detected coarse and fine mode single particles collected on filters in coastal China that were internally mixed with sulphate and nitrate. These particles also typically contained mineral elements indicative of dust. Using similar methods, significant fractions of Asian dust particles collected in Japan were also found to contain both nitrate and sulphate (Zhang et al., 2003). In both these reports, the detection of nitrate and sulphate in each particle was purely qualitative and the detection limits for nitrate and sulphate on the coated collection substrates were $10^{-14}$ and $10^{-17} \mathrm{~g}$, respectively. Thus, a mineral dust particle containing even a small amount of nitrate and/or sulphate would be reported as internally mixed with nitrate and sulphate.

The aging mechanism presented in Sect. 3.8 can be used to explain the segregation of sulphate from nitrate and chloride in dust. As sulphate is non-volatile and the strongest acid, it will prevent the accumulation of other weaker acids once it has formed in the mineral dust. The segregation therefore indicates that sulphate accumulated in the dust first. This could be the result of a faster kinetic rate for the formation of sulphate in dust compared to nitrate and chloride, and/or the dust plume encountering sulphate precursors prior to those of nitrate and chloride.

Numerous laboratories studies have measured reaction probabilities for various acidic gases with mineral dust surfaces. Most of these have involved reacting the dust with one gas at a time, though Ooki and Uematsu (2005) reacted Asian dust particles with ambient Tokyo air containing acidic gases (e.g. $\mathrm{SO}_{2}, \mathrm{NO}_{2}, \mathrm{HNO}_{3}$, and $\mathrm{HCl}$ ). In general, the reaction probabilities for $\mathrm{HNO}_{3}$ with dust are found to be several orders of magnitude higher than for $\mathrm{NO}_{2}$ or $\mathrm{SO}_{2}$ (Hanisch and Crowley, 2001; Ullerstam et al., 2003; Underwood et al., 2001; Usher et al., 2003a; Vlasenko et al., 2006). The study of Ooki and Uematsu (2005) is the only one we are aware of that has studied the reaction of $\mathrm{HCl}(\mathrm{g})$ with dust particles. They found that the dust predominantly reacted with $\mathrm{HNO}_{3}(48 \%)$ and $\mathrm{HCl}(40 \%)$, and not with $\mathrm{SO}_{2}(12 \%)$; no reaction probabilities were determined. Santschi and Rossi (2006) measured the reaction probability for $\mathrm{HCl}(\mathrm{g})$ on calcite to be 0.1 , which was the same value they found for $\mathrm{HNO}_{3}$ and $\mathrm{SO}_{2}$. They stressed the role that adsorbed water plays in the kinetics.

While $\mathrm{HNO}_{3}$ and $\mathrm{HCl}$ exhibit much higher reaction probabilities than $\mathrm{SO}_{2}$ or $\mathrm{NO}_{2}$, the latter two gases are typically 
present in much higher concentrations in the lower atmosphere than either $\mathrm{HNO}_{3}$ or $\mathrm{HCl}$, and thus the actual rate of reaction of these four gases with dust may be quite similar. The fact that sulphate appears to accumulate first in the aged dust (Fig. 3b) despite the fact that the reaction probability for $\mathrm{SO}_{2}$ with dust is 1-2 orders of magnitude less than for $\mathrm{HNO}_{3}$ or $\mathrm{HCl}$ indicates that kinetics is not the major factor controlling which acids the dust reacts with preferentially. Zhang et al. (2003) concluded that the formation of sulphate on Asian dust is more efficient than for nitrate based on a much greater abundance of dust particles that contained sulphate than nitrate. They attributed this to the greater concentrations of $\mathrm{SO}_{2}$ than $\mathrm{NO}_{\mathrm{x}}$ in East Asia and to the non-volatile nature of sulphuric acid compared to the more volatile nitric acid; both of these factors are discussed further below.

In general, the emissions of $\mathrm{SO}_{2}$ are greater than of $\mathrm{NO}_{\mathrm{x}}$ in east Asia. This difference is most pronounced in the interior due to $\mathrm{SO}_{2}$ emissions from industrial activity and coal power plants (Akimoto and Narita, 1994; Streets et al., 2003; Tang et al., 2004b). The emissions of $\mathrm{NO}_{\mathrm{x}}$ are greatest in the large urban areas near the coast, but still do not exceed those of $\mathrm{SO}_{2}$. Finally, the mixing ratios of $\mathrm{HCl}$ will be greatest in the polluted marine boundary layer primarily due to the release of $\mathrm{HCl}$ from acidified sea salt particles (Tang et al., 2004b). Thus, it is reasonable to assume that mineral dust particles being transported eastward from the interior by a cold front first encounter elevated $\mathrm{SO}_{2}$, followed by both $\mathrm{SO}_{2}$ and $\mathrm{NO}_{\mathrm{x}}$ in polluted coastal regions, and finally elevated $\mathrm{HCl}$ once over marine areas. This causes sulphate to mix with dust first, before nitrate or chloride, and explains the weak dependence of sulphate-dust concentrations on the total dust loadings (Fig. 3b). Interaction of dust with $\mathrm{SO}_{2}$ from coal burning was also used to explain the strong association between sulphate and single dust particles measured in Japan, recently reported by Matsumoto et al. (2006). Despite the numerous laboratory findings that $\mathrm{HNO}_{3}$ reacts with dust more rapidly than $\mathrm{SO}_{2}$ does, sulphate accumulates in the dust first because it encounters elevated $\mathrm{SO}_{2}$ early in its transport history.

The displacement of nitrate and chloride back to the gas-phase due to the uptake of $\mathrm{SO}_{2} / \mathrm{H}_{2} \mathrm{SO}_{4}$, a stronger acid, is one possible explanation for the segregation of sulphate in mineral dust from nitrate and chloride in dust presented in Fig. 5. Mineral dust that has accumulated enough $\mathrm{SO}_{2} / \mathrm{H}_{2} \mathrm{SO}_{4}$ to neutralize any alkaline components of the dust (likely $\mathrm{CaCO}_{3}$ ) and acidify the particle will also prevent any further uptake of nitric or hydrochloric acids by that dust particle. If uptake of sulphate versus nitrate and chloride were a displacement process, numerous dust particles should appear between the $100 \% \mathrm{HSO}_{4}{ }^{-}$vertex and the $100 \% \mathrm{NO}_{3}{ }^{-}$or $100 \% \mathrm{Cl}^{-}$vertex. Figure 5 clearly shows a lack of significant numbers of particles in these areas. This indicates that the earlier mixing of dust with sulphate precursors was the likely cause of this segregation, not displacement. The chemical mineralogy of dust also plays an impor- tant role in determining which acids will preferentially react with dust. Together these processes explain the segregation of sulphate from nitrate and chloride in dust particles.

\subsection{Comparison with STEM-2K3 regional model and modeling recommendations}

The regional transport model, STEM-2K3, was employed to simulate the evolution of aerosol size and composition in east Asia during the ACE-Asia campaign. The extensive results of these simulations in relation to the Asian dust event are described by Tang et al. (2004a, b). A good comparison of ATOFMS data and STEM-2K3 simulations for the degree of sea salt aging has already been reported (Tang et al., 2004b). The model simulation captures the shift in particulate nitrate from aged sea salt to dust particles that we observed when the dust front arrived. Regarding mineral dust chemistry, the simulations find the presence of Asian dust enhances the production of sulphate and nitrate and increases the supermicron fraction of these species, due to the large size of the dust particles. The production of sulphate increases by $10-40 \%$, with much of this additional sulphate forming in supermicron particles. More than $80 \%$ of nitrate and $10-30 \%$ of sulphate is found to exist in the supermicron mode (all particle types) during dust events. This agrees with the size distributions we presented in Fig. 11. The model and other observations also find ammonium is restricted to the submicron mode, which is mostly in agreement with our single-particle dust results. Figure $11 \mathrm{~b}$ shows that a small fraction of supermicron dust contains ammonium. The simulations find that the concentration of nitrate is more sensitive to dust loadings than that of sulphate. This agrees with our finding that nitrate-dust (and chloride-dust) is more sensitive to total dust concentrations than sulphate-dust is (Fig. 3b). Tang et al. (2004b) also discuss the importance of the elevated $\mathrm{SO}_{2}$ emissions in the interior of China (Sichuan basin), which leads to higher concentrations of sulphate in the interior, while nitrate and ammonium are maximized in the east towards the coast. They find that sulphate loadings exceed nitrate throughout most of the region, due to the significantly higher $\mathrm{SO}_{2}$ emissions, which are a factor of 3 larger (by mass) than $\mathrm{NO}_{\mathrm{x}}$ emissions. This agrees with the timeline we presented in Sect. 3.9 in which dust encounters elevated $\mathrm{SO}_{2}$ before $\mathrm{NO}_{\mathrm{x}}$ and $\mathrm{HCl}$, which explains the dust-loading dependence in Fig. $3 \mathrm{~b}$ and the segregation of sulphate from nitrate and chloride (Fig. 5). In general, the simulations from the STEM-2K3 model are in excellent agreement with our single-particle dust observations, especially in determining the size distributions of secondary inorganic species in dust-impacted aerosol.

One area where the ATOFMS field data and the model simulations disagree concerns the formation of ammonium on dust. Tang et al. (2004b) state "if $\mathrm{NH}_{3}$ concentrations are in excess of that needed to neutralise sulphate, then $\mathrm{NH}_{4} \mathrm{NO}_{3}$ can exist in the fine mode, even in the presence of dust." However, our data strongly indicate that a large fraction of 
the dust aerosol was largely acidic (Figs. 3, 4 and 11), especially for submicron dust, based on the segregation of sulphate and nitrate from each other. Regardless, $42 \%$ of the sulphate-dust and $31 \%$ of the nitrate-dust was also internally mixed with ammonium, on average. This implies that while there was not enough ammonia to neutralise all the acid in the dust, ammonia still partitioned to the aged dust to a significant extent. Jordan et al. (2003) drew a similar conclusion from their TRACE-P data as Tang et al. did, arguing against the association of ammonium with nitrate and sulphate in the presence of dust. We have demonstrated that ammonium is internally mixed with nitrate and sulphate in the dust-impacted aerosol, suggesting a re-evaluation of these previous statements.

Many studies, including this one, have shown the importance that dust mineralogy plays in affecting atmospheric chemistry reaction pathways. The STEM-2K3 model accounted for this by assuming a certain fraction of the calcium carbonate in the dust was available for reaction. This remains an important but still uncertain parameter. More detailed descriptions that capture the heterogeneity of the chemical composition of dust at the single-particle level are required to more accurately model its chemistry, though this will be computationally expensive. Our observations of sulphate being segregated from nitrate and chloride in dust indicate that it is not accurate to treat dust as one internally mixed component in aerosol models. The role that relative humidity and the availability of carbonate, iron, and other reactive dust components play in the chemical kinetics remain important issues under investigation that need to be incorporated into aerosol chemical models. As the STEM-2K3 model has done, it is important to accurately model not only the dust composition and kinetic rates, but also the spatial distributions of gas emissions and the timeline that the aerosol encounters these reactants. As our observations suggest, the concentrations and order in which the dust reacts with various gaseous pollutants can be more important than the reaction kinetics alone.

\section{Atmospheric implications and conclusions}

ATOFMS measurements of individual dust particles during ACE-Asia show significant fractions of the dust were internally mixed with secondary acids and ammonium. To our knowledge, this is the first report of the segregation of sulphate from nitrate and chloride in individual dust particles. The sulphate appears to accumulate in the dust before nitrate and chloride. These results are explained by a transport timeline in which the dust plume encounters elevated $\mathrm{SO}_{2}(\mathrm{~g})$ in the interior near the dust source before mixing with $\mathrm{NO}_{\mathrm{y}}(\mathrm{g})$ and $\mathrm{HCl}(\mathrm{g})$ in coastal areas. The significant uptake of chloride (not from sea salt agglomeration) by dust was caused by reaction with $\mathrm{HCl}(\mathrm{g})$ released from acidified sea salt. The prior reaction of nitrate and sulphate precursors with sea salt particles reduced the availability for nitrate and sulphate to form on dust while simultaneously releasing $\mathrm{HCl}(\mathrm{g})$. Laboratory studies of the competitive reaction of various acidic gases with mineral dust particles are required to investigate the novel segregation results reported here. This segregation and preferential temporal uptake of secondary acids has important implications for the accurate modeling of the troposphere's gas and particle phase composition during dust events. This must be accounted for when modeling the evolution of dust particles during atmospheric transport and processing as it will affect the ability of aged dust to react further with trace gases, and alter the atmospheric lifetime of dust.

Nitrate and chloride were enriched in supermicron dust while sulphate and ammonium were enriched in the submicron mode. This size distribution of secondary acids in dust provides direct evidence in support of model mechanisms of mineral dust aging, using single-particle measurements of size-segregated dust particles not mixed with sea salt to confirm these models' predictions. Ammonium was only found in dust particles also containing secondary acids and the amount of ammonium strongly correlated with the sum of acids in the dust. Ammonium salts were internally mixed with dust particles, especially in the submicron mode, contrary to previous suggestions that submicron ammonium sulphate is externally mixed from dust. Based on these findings, the common assumption that submicron ammonium sulphate and mineral dust particles are externally mixed should be revisited.

The mixing of dust with secondary acids and ammonium has significant implications for the chemical composition of the troposphere, as well as the chemical, physical and optical properties of dust laden aerosol populations and their subsequent climactic effects. The reaction of $\mathrm{NO}_{\mathrm{y}}$ and $\mathrm{SO}_{\mathrm{x}}$ species with dust can cause significant changes in the partitioning of trace reactive species between the gas and particle phase (Tang et al., 2004a). The uptake of hydrochloric acid by mineral dust has recently been demonstrated in this and previous reports (Murphy et al., 2006; Ooki and Uematsu, 2005; Sullivan et al., 2006 ${ }^{1}$; Zhang and Iwasaka, 2001) and must also be considered in models of tropospheric chemistry. Mixing of secondary acids and ammonium with supermicrondominated dust in dust plumes causes a shift of these species from submicron to supermicron particles. During ACE-Asia, this led to a decrease in the overall hygroscopicity of the aerosol population and removed aerosol mass from the optically efficient accumulation size mode (Arimoto et al., 2006; Carrico et al., 2003; Quinn et al., 2004). The addition of soluble material to dust can modify its CCN and IN ability, thus changing the cloud formation properties and lifetime of dust aerosols. Mixing dust with secondary species can also alter the dust's direct radiative properties (Bauer and Koch, 2005; Conant et al., 2003). The segregation of nitrate from sulphate in dust particles will also impart different physical and chemical properties to the aged dust. For example, calcium nitrate is highly soluble and readily deliquesces (Gib- 
son et al., 2006), while calcium sulphate is very hygroscopic but rather insoluble. This has important implications for the solubility and phase of aged dust particles in the atmosphere.

During ACE-Asia, dust also scavenged semivolatile organic compounds, shifting them from the submicron to supermicron size range (Clarke et al., 2004). This had the interesting and important result of decreasing the scattering efficiency of the submicron particles and thus increasing the absorption efficiency of the black carbon dominated submicron aerosol. The partitioning of sulphate and nitrate to supermicron-dominated dust had a similar effect. The internal mixing of dust particles with elemental and/or organic carbon is an important issue which we did not discuss here. Single-particle ATOFMS data on the internal mixing of dust with carbonaceous species can provide valuable insight into these processes and their consequences, and will be the topic of a future manuscript. For example, our data shows a strong diurnal cycle of dicarboxylic acids occurring in dust over at least 25 days of the ACE-Asia campaign (Sullivan and Prather, $2007^{2}$ ).

By comparing the temporal evolution of secondary acids in dust particles of varying mineralogy, clear differences between high-Al and high-Ca dust particles were found. Sulphate was highly associated with aluminosilicate- and ironrich dust while nitrate mixed with calcium-rich dust. This further supports lab studies which suggest mineralogy plays a role in dictating the types of reactions dust undergoes in the atmosphere. This could be due to different rates of reaction/formation of different acids with specific crustal minerals. The fact that the uptake of acids displayed a strong mineralogical dependence is further evidence for heterogeneous uptake of the acids. If the secondary acids had become mixed with the dust primarily through coagulation, cloud processing, or heterogeneous nucleation, we would not expect such a strong dependence on the dust's mineralogy (Matsuki et al., 2005a). The effect of mineralogy deserves further attention in laboratory studies, particularly using authentic dust samples of varying composition. The dependence of the dust reactivity on its composition should also be incorporated into regional and global chemistry models (Krueger et al., 2004; Tang et al., 2004b).

The alkaline calcium carbonate neutralised nitric and hydrochloric acid, leading to the accumulation of nitrate and chloride in calcium-rich dust. We propose that the sulphate association is due to the iron-catalyzed oxidation of S(IV) to $\mathrm{S}(\mathrm{VI})$ in the iron- and aluminosilicate-rich dust particles (Deguillaume et al., 2005; Qi et al., 2006; Rani et al., 1992; Zhuang et al., 1992). This process has important implications for the fertilization of remote oceans and subsequent climate system feedbacks (Duce, 1995; Jickells et al., 2005; Meskhidze et al., 2003). Iron is a key nutrient control-

\footnotetext{
${ }^{2}$ Sullivan, R. C., and Prather, K. A.: A persistent diurnal cycle of oxalic acid in Asian dust indicates photochemical production, Environ. Sci. Technol., to be submitted, 2007.
}

ling biological productivity in high-nutrient low-chlorophyll (HNLC) ocean regions. Mineral dust that deposits in the oceans is the major source of iron to these remote regions (Jickells et al., 2005). However, it is believed that it is the amount of soluble iron in the dust particles, as opposed to the total iron content, which governs the fertilization of the oceans (Jickells et al., 2005; Luo et al., 2005). The solubility of iron in dust particles can be increased as the particles become acidified by atmospheric processing and the accumulation of secondary acids (Zhu et al., 1992), such as has been shown extensively here. Submicron dust particles can be transported over longer distances than larger dust particles due to their longer atmospheric lifetimes. The accumulation of sulphate in submicron dust we demonstrated will therefore have important implications for the transport of acidified dust particles containing soluble iron to remote ocean regions (Baker and Jickells, 2006; Luo et al., 2005). Nitrate that has accumulated in mineral dust due to atmospheric processing is another important soluble nutrient for the oceans (Baker et al., 2003; Prospero and Savoie, 1989).

Fertilization of HNLC ocean regions by soluble iron in dust increases ocean productivity, phytoplankton in particular, causing a wide variety of climate feedbacks. For example, this could increase the uptake of carbon dioxide by marine organisms and also lead to increased DMS ocean emissions and thus increased cloud cover according to the CLAW hypothesis (Charlson et al., 1987; Duce, 1995; Turner et al., 2004). The resulting climate changes (wind speeds and patterns, precipitation) can then affect the production and transport of aeolian crustal material to the oceans in the first place. Our observations of mineral dust processing by pollutant gases present an important link between anthropogenic emissions and the chemistry of naturally-occurring mineral dust particles. These interactions with anthropogenic pollutants alter the impacts that a naturally produced aerosol have on the atmosphere, oceans, and climate.

\section{Appendix A}

\section{A1 Filtering criteria details}

Particles produced by biomass burning typically produce intense ${ }^{39} \mathrm{~K}^{+}$signals, in addition to organic and elemental carbon fragments. The presence of large metal ion peaks such as ${ }^{39} \mathrm{~K}^{+}$can cause biomass particles to be incorrectly placed in mineral dust clusters by the ART-2a algorithm. To correct for this, the mineral dust particles sorted by ART-2a were further filtered using a peak area ${ }^{27} \mathrm{Al}^{+}>5000$ criteria to eliminate incorrectly sorted biomass particles. The ${ }^{27} \mathrm{Al}^{+}$criteria was chosen because $\mathrm{Al}$ is generally regarded as the most common single marker for mineral dust particles (Gao and Anderson, 2001; Mori et al., 2003; Nishikawa et al., 1991; Usher et al., 2003a) and is readily detected in mineral dust by ATOFMS (Guazzotti et al., 2001a; Silva et al., 2000). From previous 
source studies, we have determined that biomass particles do not produce peak areas $>5000$ at $m / z 27$ from ${ }^{27}\left[\mathrm{C}_{2} \mathrm{H}_{3}\right]^{+}$or other organic fragments.

Mineral dust particles that were internally mixed with sea salt were queried using a peak area $>100$ units for ${ }^{81}\left[\mathrm{Na}_{2}{ }^{35} \mathrm{Cl}\right]^{+}$criterion. The $\left[\mathrm{Na}_{2} \mathrm{Cl}\right]^{+}$ion is an ideal marker for various particle types internally mixed with sea salt (Guazzotti et al., 2001a) that was not present in the Asian dust source spectra. The final set of properly-calibrated dust particles that satisfied both the ${ }^{27} \mathrm{Al}^{+}>5000$ and ${ }^{81}\left[\mathrm{Na}_{2}{ }^{35} \mathrm{Cl}\right]^{+}<100$ peak area criteria is herein referred to as "filtered dust particles". Using this criterion, the fraction of mineral dust particles internally mixed with sea salt was determined to be $15 \pm 9.5 \%$ on average over the course of the entire study. Before the dust front the fraction of dust particles internally mixed with sea salt was as high as $40 \%$ (Sullivan et al., 2006) ${ }^{1}$. While this degree of mixing is lower than previous single-particle filter-based measurements in this region (Fan et al., 1996; Zhang et al., 2003), a high degree of dust-sea salt mixing is typically caused by cloud processing. If the dust-laden air mass did not pass through a dense convective cloud system before reaching the RHB, this would explain the lower level of internal mixing. This may also be explained by the $0.2-3.0 \mu \mathrm{m}$ particle size range measured by the ATOFMS. The mixing of a dust particle with sea salt has been shown to increase the dust particle's diameter by $\sim 0.4-0.8 \mu \mathrm{m}$ (Zhang and Iwasaka, 2004) and the peak in the number-weighted size distribution of mixed dust and sea salt particles is typically near or above $3 \mu \mathrm{m}$ (Zhang et al., 2003). During the ACE-Asia dust event, the coarse-mode volume distribution peaked at $\sim 4.0 \mu \mathrm{m}$ (Bates et al., 2004), implying that a large fraction of the internally mixed dust and sea-salt particles, if present, likely had diameters $>3.0 \mu \mathrm{m}$ and were therefore not detected by ATOFMS.

\section{A2 Typical peak area ranges}

What follows is a summary of typical ion peak areas measured by the ATOFMS for various chemical species in mineral dust particles. Peaks with areas $<25$ are generally considered to be in the noise. For the secondary inorganic species, an area $<500$ is not considered large and is of the magnitude that can be measured in source dust spectra. This does not apply to ammonium, however, which is not commonly measured in the source dust with a peak area $>50$. A peak area $>20000$ for secondary inorganics is a very large value that is never observed in the source dust and is not commonly seen in the ambient aged dust spectra. Thus, it reflects a very large amount of a secondary inorganic species, likely due to extensive aging. Peak areas up to and exceeding 40000 have been observed (see Fig. 5 for example). The peak area of 5000, though not yet quantified, represents a significant amount of secondary inorganic material beyond that detected in any source sample. A list of typical peak areas used to search for various particulate species in ATOFMS data is given in Liu et al. (2003). Table 1 lists ion assignments for peaks commonly observed by the ATOFMS from mineral dust particles.

\section{A3 Ammonium in dust queries}

To investigate if ammonium was only associated with dust particles which also contained nitrate, sulphate, or chloride, all filtered dust particles with a peak area $>1000$ for ${ }^{18}\left[\mathrm{NH}_{4}\right]^{+}$were queried, returning 8870 particles for DOY 98-105. 4208 of these were dust particles also mixed with nitrate, 1846 were mixed with sulphate, and 1087 were mixed with chloride. Together dust mixed with one or more of the three acids accounted for $73 \%$ of the ammonium-containing dust. The remaining ammonium-dust particles can be explained by having significant signals for chloride, nitrate, and sulphate (i.e. peak area $>1000$ ) that did not exceed the 5000 peak area threshold. More detailed statistics of the mixing state of dust with ammonium and secondary acids are given in Fig. 4. There were no indications in the average mass spectra that the ammonium was present in dust particles that did not also contain secondary acids to some extent. This was also confirmed by peak area searches within this subset. Therefore, ammonium was only found in dust particles that also contained acidic species such as nitric, sulphuric, and, to a lesser extent, hydrochloric acids.

The temporal correlations of chloride-dust and dust mixed with both ammonium and chloride (not shown), thus containing ammonium chloride, were not as significant as those for ammonium sulphate or ammonium nitrate. There were two time periods when ammonium chloride-dust was detected and these both occurred when chloride-dust dominated. The largest of these was from DOY 108.88-102.38 (Dust \& Korea period) when $29.8 \%$ of the 1087 total ammonium chloride-dust particles were detected over just $13 \mathrm{~h}$. From DOY 103.0-105.0 (Dust \& Shanghai period) 52.4\% were detected. There were no significant counts of ammonium chloride-dust during the first Dust Front period (DOY 101) when the initial large increase in chloride-dust occurred.

Acknowledgements. We thank Irina Sokolik and her group for providing the Asian dust source samples and Keith Coffee for collecting the source dust mass spectra. We thank Vicki Grassian and Dan Murphy for valuable discussions regarding these results. Our participation in the ACE-Asia campaign was funded by the National Science Foundation.

Edited by: Y. Rudich 


\section{References}

Akimoto, $\mathrm{H}$. and Narita, $\mathrm{H}$.: Distribution of $\mathrm{SO}_{2}, \mathrm{NO}_{\mathrm{x}}$ and $\mathrm{CO}_{2}$ emissions from fuel combustion and industrial activities in Asia with 1-degrees-x1-degrees resolution, Atmos. Environ., 28(2), 213-225, 1994.

Al-Hosney, H. A., Carlos-Cuellar, S., Baltrusaitis, J., and Grassian, V. H.: Heterogeneous uptake and reactivity of formic acid on calcium carbonate particles: a Knudsen cell reactor, FTIR and SEM study, Phys. Chem. Chem. Phys., 7(20), 3587-3595, 2005.

Al-Hosney, H. A. and Grassian, V. H.: Water, sulfur dioxide and nitric acid adsorption on calcium carbonate: A transmission and ATR-FTIR study, Phys. Chem. Chem. Phys., 7(6), 1266-1276, 2005.

Andreae, M. O., Charlson, R. J., Bruynseels, F., Storms, H., Vangrieken, R., and Maenhaut, W.: Internal mixture of sea salt, silicates, and excess sulfate in marine aerosols, Science, 232(4758), 1620-1623, 1986.

Andronova, A. V., Gomes, L., Smirnov, V. V., Ivanov, A. V., and Shukurova, L. M.: Physicochemical characteristics of dust aerosols deposited during the Soviet-American eperiment (Tajikistan, 1989), Atmos. Environ., Part A: General Topics, 27(16), 2487-2493, 1993.

Angelino, S., Suess, D. T., and Prather, K. A.: Formation of aerosol particles from reactions of secondary and tertiary alkylamines: Characterization by aerosol time-of-flight mass spectrometry, Environ. Sci. Technol., 35(15), 3130-3138, 2001.

Arimoto, R., Kim, Y. J., Kim, Y. P., Quinn, P. K., Bates, T. S., Anderson, T. L., Gong, S., Uno, I., Chin, M., Huebert, B. J., Clarke, A. D., Shinozuka, Y., Weber, R. J., Anderson, J. R., Guazzotti, S. A., Sullivan, R. C., Sodeman, D. A., Prather, K. A., and Sokolik, I. N.: Characterization of Asian Dust during ACE-Asia, Global Planet. Change, 52(1-4), 23-56, 2006.

Arimoto, R., Zhang, X. Y., Huebert, B. J., Kang, C. H., Savoie, D. L., Prospero, J. M., Sage, S. K., Schloesslin, C. A., Khaing, H. M., and Oh, S. N.: Chemical composition of atmospheric aerosols from Zhenbeitai, China, and Gosan, South Korea, during ACE-Asia, J. Geophys. Res., 109(D19), D19S04, doi:10.1029/2003JD004323, 2004.

Baker, A. R. and Jickells, T. D.: Mineral particle size as a control on aerosol iron solubility, Geophys. Res. Lett., 33, L17608, doi:10.1029/2006GL026557, 2006.

Baker, A. R., Kelly, S. D., Biswas, K. F., Witt, M., and Jickells, T. D.: Atmospheric deposition of nutrients to the Atlantic Ocean, Geophys. Res. Lett., 30(24), 2296, doi:10.1029/2003GL018518, 2003.

Bassett, M. E. and Seinfeld, J. H.: Atmospheric equilibrium-model of sulfate and nitrate aerosols. 2. Particle-size analysis, Atmos. Environ., 18(6), 1163-1170, 1984.

Bates, T. S., Quinn, P. K., Coffman, D. J., Covert, D. S., Miller, T. L., Johnson, J. E., Carmichael, G. R., Uno, I., Guazzotti, S. A., Sodeman, D. A., Prather, K. A., Rivera, M., Russell, L. M., and Merrill, J. T.: Marine boundary layer dust and pollutant transport associated with the passage of a frontal system over eastern Asia, J. Geophys. Res., 109(D19), D19S19, doi:10.1029/2003JD004094, 2004.

Bauer, S. E., Balkanski, Y., Schulz, M., Hauglustaine, D. A., and Dentener, F.: Global modeling of heterogeneous chemistry on mineral aerosol surfaces: Influence on tropospheric ozone chemistry and comparison to observations, J. Geophys. Res., 109(D2),
D02304, doi:10.1029/2003JD003868, 2004.

Bauer, S. E. and Koch, D.: Impact of heterogeneous sulfate formation at mineral dust surfaces on aerosol loads and radiative forcing in the Goddard Institute for Space Studies general circulation model, J. Geophys. Res., 110(D17), D17202, doi:10.1029/2005JD005870, 2005.

Bian, H. S. and Zender, C. S.: Mineral dust and global tropospheric chemistry: Relative roles of photolysis and heterogeneous uptake, J. Geophys. Res., 108(D21), 8672, doi:10.1029/2002JD003143, 2003.

Bishop, J. K. B., Davis, R. E., and Sherman, J. T.: Robotic observations of dust storm enhancement of carbon biomass in the North Pacific, Science, 298(5594), 817-821, 2002.

Brandt, C. and Vaneldik, R.: Transition-metal-catalyzed oxidation of sulfur(IV) oxides - atmospheric-relevant processes and mechanisms, Chem. Rev., 95(1), 119-190, 1995.

Bruynseels, F. J. and Van Grieken, R. E.: Molecular ion distributions in laser microprobe mass spectrometry of calcium oxide and calcium salts, Spectrochimica Acta, Part B: Atomic Spectroscopy, 38B(5-6), 853-858, 1983.

Cahill, C. F.: Asian aerosol transport to Alaska during ACE-Asia, J. Geophys. Res., 108(D23), 8664, doi:10.1029/2002JD003271, 2003.

Carlos-Cuellar, S., Li, P., Christensen, A. P., Krueger, B. J., Burrichter, C., and Grassian, V. H.: Heterogeneous uptake kinetics of volatile organic compounds on oxide surfaces using a Knudsen cell reactor: Adsorption of acetic acid, formaldehyde, and methanol on alpha- $\mathrm{Fe}_{2} \mathrm{O}_{3}$, alpha- $\mathrm{Al}_{2} \mathrm{O}_{3}$, and $\mathrm{SiO}_{2}$, J. Phys. Chem. A, 107(21), 4250-4261, 2003.

Carrico, C. M., Kus, P., Rood, M. J., Quinn, P. K., and Bates, T. S.: Mixtures of pollution, dust, sea salt, and volcanic aerosol during ACE-Asia: Radiative properties as a function of relative humidity, J. Geophys. Res.-Atmos., 108(D23), 8650, doi:10.1029/2003JD003405, 2003.

Chang, R. Y. W., Sullivan, R. C., and Abbatt, J. P. D.: Initial uptake of ozone on Saharan dust at atmospheric relative humidities, Geophys. Res. Lett., 32(14), L14815, doi:10.1029/2005GL023317, 2005.

Charlson, R. J., Lovelock, J. E., Andreae, M. O., and Warren, S. G.: Oceanic phytoplankton, atmospheric sulfur, cloud albedo and climate, Nature, 326(6114), 655-661, 1987.

Clarke, A. D., Shinozuka, Y., Kapustin, V. N., Howell, S., Huebert, B., Doherty, S., Anderson, T., Covert, D., Anderson, J., Hua, X., Moore, K. G., McNaughton, C., Carmichael, G., and Weber, R.: Size distributions and mixtures of dust and black carbon aerosol in Asian outflow: Physiochemistry and optical properties, J. Geophys. Res., 109(D15), D15S09, doi:10.1029/2003JD004378, 2004.

Conant, W. C., Seinfeld, J. H., Wang, J., Carmichael, G. R., Tang, Y. H., Uno, I., Flatau, P. J., Markowicz, K. M., and Quinn, P. K.: A model for the radiative forcing during ACE-Asia derived from CIRPAS Twin Otter and R/V Ronald H. Brown data and comparison with observations, J. Geophys. Res., 108(D23), 8661, doi:10.1029/2002JD003260, 2003.

Cziczo, D. J., Murphy, D. M., Hudson, P. K., and Thomson, D. S.: Single particle measurements of the chemical composition of cirrus ice residue during CRYSTAL-FACE, J. Geophys. Res., 109(D4), D04201, doi:10.1029/2003JD004032, 2004.

de Reus, M., Dentener, F., Thomas, A., Borrmann, S., Strom, J., 
and Lelieveld, J.: Airborne observations of dust aerosol over the North Atlantic Ocean during ACE 2: Indications for heterogeneous ozone destruction, J. Geophys. Res.-Atmos., 105(D12), $15263-15275,2000$.

Deguillaume, L., Leriche, M., Desboeufs, K., Mailhot, G., George, C., and Chaumerliac, N.: Transition metals in atmospheric liquid phases: Sources, reactivity, and sensitive parameters, Chem. Rev., 105(9), 3388-3431, 2005.

DeMott, P. J., Sassen, K., Poellot, M. R., Baumgardner, D., Rogers, D. C., Brooks, S. D., Prenni, A. J., and Kreidenweis, S. M.: African dust aerosols as atmospheric ice nuclei, Geophys. Res. Lett., 30(14), 1732, doi:10.1029/2003GL017410, 2003.

Dentener, F. J., Carmichael, G. R., Zhang, Y., Lelieveld, J., and Crutzen, P. J.: Role of mineral aerosol as a reactive surface in the global troposphere, J. Geophys. Res.-Atmos., 101(D17), 22 869$22889,1996$.

Derbyshire, E., Meng, X. M., and Kemp, R. A.: Provenance, transport and characteristics of modern aeolian dust in western Gansu Province, China, and interpretation of the Quaternary loess record, J. Arid Environ., 39(3), 497-516, 1998.

Duce, R. A.: Sources, distributions, and fluxes of mineral aerosols and their relationship to climate, in: Aerosol forcing of climate, edited by: Charlson, R. J. and Heintzenberg, J., John Wiley \& Sons Ltd., Chichester, England, 1995.

Duce, R. A., Unni, C. K., Ray, B. J., Prospero, J. M., and Merrill, J. T.: Long-range atmospheric transport of soil dust from Asia to the tropical North Pacific - temporal variability, Science, 209(4464), 1522-1524, 1980.

Falkovich, A. H., Ganor, E., Levin, Z., Formenti, P., and Rudich, Y.: Chemical and mineralogical analysis of individual mineral dust particles, J. Geophys. Res.-Atmos., 106(D16), 18 029-18 036, 2001.

Fan, X. B., Okada, K., Niimura, N., Kai, K., Arao, K., Shi, G. Y., Qin, Y., and Mitsuta, Y.: Mineral particles collected in China and Japan during the same Asian dust-storm event, Atmos. Environ., 30(2), 347-351, 1996.

Gao, Y. and Anderson, J. R.: Characteristics of Chinese aerosols determined by individual-particle analysis, J. Geophys. Res.Atmos., 106(D16), 18 037-18 045, 2001.

Gard, E., Mayer, J. E., Morrical, B. D., Dienes, T., Fergenson, D. P., and Prather, K. A.: Real-time analysis of individual atmospheric aerosol particles: Design and performance of a portable ATOFMS, Anal. Chem., 69(20), 4083-4091, 1997.

Gard, E. E., Kleeman, M. J., Gross, D. S., Hughes, L. S., Allen, J. O., Morrical, B. D., Fergenson, D. P., Dienes, T., Galli, M. E., Johnson, R. J., Cass, G. R., and Prather, K. A.: Direct observation of heterogeneous chemistry in the atmosphere, Science, 279(5354), 1184-1187, 1998.

Gibson, E. R., Hudson, P. K., and Grassian, V. H.: Aerosol chemistry and climate: Laboratory studies of the carbonate component of mineral dust and its reaction products, Geophys. Res. Lett., 33(13), L13811, doi:10.1029/2006GL026386, 2006.

Ginoux, P., Chin, M., Tegen, I., Prospero, J. M., Holben, B., Dubovik, O., and Lin, S. J.: Sources and distributions of dust aerosols simulated with the GOCART model, J. Geophys. Res., 106(D17), 20 255-20 273, 2001.

Gong, S. L., Zhang, X. Y., Zhao, T. L., McKendry, I. G., Jaffe, D. A., and Lu, N. M.: Characterization of soil dust aerosol in China and its transport and distribution during 2001 ACE-Asia:
2. Model simulation and validation, J. Geophys. Res.-Atmos., 108(D9), 4262, doi:10.1029/2002JD002633, 2003.

Goodman, A. L., Bernard, E. T., and Grassian, V. H.: Spectroscopic study of nitric acid and water adsorption on oxide particles: Enhanced nitric acid uptake kinetics in the presence of adsorbed water, J. Phys. Chem. A, 105(26), 6443-6457, 2001.

Grassian, V. H.: Chemical reactions of nitrogen oxides on the surface of oxide, carbonate, soot, and mineral dust particles: Implications for the chemical balance of the troposphere, J. Phys. Chem. A, 106(6), 860-877, 2002.

Guazzotti, S. A., Coffee, K. R., and Prather, K. A.: Continuous measurements of size-resolved particle chemistry during INDOEXIntensive Field Phase 99, J. Geophys. Res.-Atmos., 106(D22), 28 607-28 627, 2001a.

Guazzotti, S. A., Whiteaker, J. R., Suess, D., Coffee, K. R., and Prather, K. A.: Real-time measurements of the chemical composition of size-resolved particles during a Santa Ana wind episode, California USA, Atmos. Environ., 35(19), 3229-3240, $2001 \mathrm{~b}$.

Hanisch, F. and Crowley, J. N.: Heterogeneous reactivity of gaseous nitric acid on $\mathrm{Al}_{2} \mathrm{O}_{3}, \mathrm{CaCO}_{3}$, and atmospheric dust samples: A Knudsen cell study, J. Phys. Chem. A, 105(13), 3096-3106, 2001.

Hanisch, F. and Crowley, J. N.: Heterogeneous reactivity of NO and $\mathrm{HNO}_{3}$ on mineral dust in the presence of ozone, Phys. Chem. Chem. Phys., 5(5), 883-887, 2003a.

Hanisch, F. and Crowley, J. N.: Ozone decomposition on Saharan dust: an experimental investigation, Atmos. Chem. Phys., 3, 119-130, 2003b.

Honda, M., Yabuki, S., and Shimizu, H.: Geochemical and isotopic studies of aeolian sediments in China, Sedimentology, 51(2), 211-230, 2004.

Houghton, J. T., Ding, Y., Griggs, D. J., Noguer, M., van der Linden, P. J., Dai, X., Maskell, K., and Jonhnson, C. A., Climate Change 2001: The Scientific Basis, Cambridge University Press, Cambridge, 2001.

Huebert, B. J., Bates, T., Russell, P. B., Shi, G. Y., Kim, Y. J., Kawamura, K., Carmichael, G., and Nakajima, T.: An overview of ACE-Asia: Strategies for quantifying the relationships between Asian aerosols and their climatic impacts, J. Geophys. Res.Atmos., 108(D23), 8633, doi:10.1029/2003JD003550, 2003.

Jaffe, D., Anderson, T., Covert, D., Kotchenruther, R., Trost, B., Danielson, J., Simpson, W., Berntsen, T., Karlsdottir, S., Blake, D., Harris, J., Carmichael, G., and Uno, I.: Transport of Asian air pollution to North America, Geophys. Res. Lett., 26(6), 711714, 1999.

Jeong, G. Y. and Chun, Y.: Nanofiber calcite in Asian dust and its atmospheric roles, Geophys. Res. Lett., 33, L24802, doi:10.1029/2006GL028280, 2006.

Jickells, T. D., An, Z. S., Andersen, K. K., Baker, A. R., Bergametti, G., Brooks, N., Cao, J. J., Boyd, P. W., Duce, R. A., Hunter, K. A., Kawahata, H., Kubilay, N., laRoche, J., Liss, P. S., Mahowald, N., Prospero, J. M., Ridgwell, A. J., Tegen, I., and Torres, R.: Global iron connections between desert dust, ocean biogeochemistry, and climate, Science, 308(5718), 67-71, 2005.

Jickells, T. D. and Spokes, L. J., Atmopspheric iron inputs to the oceans, in: The biogeochemistry of iron in seawater, edited by: Turner, D. R. and Hunter, K. A., John Wiley \& Sons Ltd., Chichester, England, 2001.

Johnson, E. R., Sciegienka, J., Carlos-Cuellar, S., and Grassian, V. 
H.: Heterogeneous uptake of gaseous nitric acid on dolomite $\left(\mathrm{CaMg}\left(\mathrm{CO}_{3}\right)_{2}\right)$ and calcite $\left(\mathrm{CaCO}_{3}\right)$ particles: A knudsen cell study using multiple, single, and fractional particle layers, J. Phys. Chem. A, 109(31), 6901-6911, 2005.

Jordan, C. E., Dibb, J. E., Anderson, B. E., and Fuelberg, H. E.: Uptake of nitrate and sulfate on dust aerosols during TRACE-P, J. Geophys. Res., 108(D21), 8817, doi:10.1029/2002JD003101, 2003.

Karagulian, F. and Rossi, M. J.: The heterogeneous chemical kinetics of $\mathrm{NO}_{3}$ on atmospheric mineral dust surrogates, Phys. Chem. Chem. Phys., 7(17), 3150-3162, 2005.

Kaufman, Y. J., Koren, I., Remer, L. A., Rosenfeld, D., and Rudich, Y.: The effect of smoke, dust, and pollution aerosol on shallow cloud development over the Atlantic Ocean, Proc. Natl. Acad. Sci. USA, 102(32), 11 207-11 212, 2005.

Kelly, J. T. and Wexler, A. S.: Thermodynamics of carbonates and hydrates related to heterogeneous reactions involving mineral aerosol, J. Geophys. Res.-Atmos., 110(D11), D11201, doi:10.1029/2004JD005583, 2005.

Korhonen, H., Napari, I., Timmreck, C., Vehkamaki, H., Pirjola, L., Lehtinen, K. E. J., Lauri, A., and Kulmala, M.: Heterogeneous nucleation as a potential sulphate-coating mechanism of atmospheric mineral dust particles and implications of coated dust on new particle formation, J. Geophys. Res., 108(D17), 4546, doi:10.1029/2003JD003553, 2003.

Krueger, B. J., Grassian, V. H., Cowin, J. P., and Laskin, A.: Heterogeneous chemistry of individual mineral dust particles from different dust source regions: the importance of particle mineralogy, Atmos. Enviro., 38(36), 6253-6261, 2004.

Krueger, B. J., Grassian, V. H., Laskin, A., and Cowin, J. P.: The transformation of solid atmospheric particles into liquid droplets through heterogeneous chemistry: Laboratory insights into the processing of calcium containing mineral dust aerosol in the troposphere, Geophys. Res. Lett., 30(3), 1148, doi:10.1029/2002GL016563, 2003.

Laskin, A., Iedema, M. J., Ichkovich, A., Graber, E. R., Taraniuk, I., and Rudich, Y.: Direct observation of completely processed calcium carbonate dust particles, Faraday Discuss., 130, 453468, 2005.

Levin, Z., Ganor, E., and Gladstein, V.: The effects of desert particles coated with sulfate on rain formation in the eastern Mediterranean, J. Appl. Meteorol., 35(9), 1511-1523, 1996.

Levin, Z., Teller, A., Ganor, E., and Yin, Y.: On the interactions of mineral dust, sea-salt particles, and clouds: A measurement and modeling study from the Mediterranean Israeli Dust Experiment campaign, J. Geophys. Res., 110(D20), D20202, doi:10.1029/2005JD005810, 2005.

Liu, D. Y., Wenzel, R. J., and Prather, K. A.: Aerosol timeof-flight mass spectrometry during the Atlanta Supersite Experiment: 1. Measurements, J. Geophys. Res., 108(D7), 8426, doi:10.1029/2001JD001562, 2003.

Luo, C., Mahowald, N. M., Meskhidze, N., Chen, Y., Siefert, R. L., Baker, A. R., and Johansen, A. M.: Estimation of iron solubility from observations and a global aerosol model, J. Geophys. Res., 110(D23), D23307, doi:10.1029/2005JD006059, 2005.

Mamane, Y. and Gottlieb, J.: Heterogeneous reactions of minerals with sulfur and nitrogen-oxides, J. Aerosol Sci., 20(3), 303-311, 1989.

Matsuki, A., Iwasaka, Y., Shi, G. Y., Chen, H. B., Osada, K., Zhang,
D., Kido, M., Inomata, Y., Kim, Y. S., Trochkine, D., Nishita, C., Yamada, M., Nagatani, T., Nagatani, M., and Nakata, H.: Heterogeneous sulfate formation on dust surface and its dependence on mineralogy: Balloon-borne observations from ballon-borne measurements in the surface of Beijing, China, Water, Air, and Soil Pollution: Focus, 5, 101-132, 2005a.

Matsuki, A., Iwasaka, Y., Shi, G. Y., Zhang, D. Z., Trochkine, D., Yamada, M., Kim, Y. S., Chen, B., Nagatani, T., Miyazawa, T., Nagatani, M., and Nakata, H.: Morphological and chemical modification of mineral dust: Observational insight into the heterogeneous uptake of acidic gases, Geophys. Res. Lett., 32(22), L22806, doi:10.1029/2005GL024176, 2005b.

Matsumoto, J., Takahashi, K., Matsumi, Y., Yabushita, A., Shimizu, A., Matsui, I., and Sugimoto, N.: Scavenging of pollutant acid substances by Asian mineral dust particles, Geophys. Res. Lett., 33(7), L07816, doi:10.1029/2006GL025782, 2006.

Meskhidze, N., Chameides, W. L., Nenes, A., and Chen, G.: Iron mobilization in mineral dust: Can anthropogenic $\mathrm{SO}_{2}$ emissions affect ocean productivity?, Geophys. Res. Lett., 30(21), 2085, doi:10.1029/2003GL018035, 2003.

Mori, I., Nishikawa, M., and Iwasaka, Y.: Chemical reaction during the coagulation of ammonium sulphate and mineral particles in the atmosphere, Sci. Total Environ., 224(1-3), 87-91, 1998.

Mori, I., Nishikawa, M., Tanimura, T., and Quan, H.: Change in size distribution and chemical composition of kosa (Asian dust) aerosol during long-range transport, Atmos. Environ.t, 37(30), 4253-4263, 2003.

Murphy, D. M., Cziczo, D. J., Froyd, K. D., Hudson, P. K., Matthew, B. M., Middlebrook, A. M., Peltier, R. E., Sullivan, A., Thomson, D. S., and Weber, R. J.: Single-particle mass spectrometry of tropospheric aerosol particles, J. Geophys. Res., 111(D23), D23S32, doi:10.1029/2006JD007340, 2006.

Murphy, D. M. and Thomson, D. S.: Chemical composition of single aerosol particles at Idaho Hill: Negative ion measurements, J. Geophys. Res., 102(D5), 6353-6368, 1997.

Niimura, N., Okada, K., Fan, X. B., Kai, K., Arao, K., Shi, G. Y., and Takahashi, S.: Formation of Asian dust-storm particles mixed internally with sea salt in the atmosphere, Journal of the Meteorological Society of Japan, 76(2), 275-288, 1998.

Nishikawa, M., Hao, Q., and Morita, M.: Preparation and evaluation of certified reference matreials for Asian mineral dust, Global Environ. Res., 4(1), 103-113, 2000.

Nishikawa, M., Kanamori, S., Kanamori, N., and Mizoguchi, T.: Kosa aerosol as eolian carrier of anthropogenic material, Sci. Total Environ., 107, 13-27, 1991.

Noble, C. A. and Prather, K. A.: Real-time measurement of correlated size and composition profiles of individual atmospheric aerosol particles, Environ. Sci. Technol., 30(9), 2667-2680, 1996.

Ooki, A. and Uematsu, M.: Chemical interactions between mineral dust particles and acid gases during Asian dust events, J. Geophys. Res.-Atmos., 110(D3), D03201, doi:10.1029/2004JD004737, 2005.

Pastor, S. H., Allen, J. O., Hughes, L. S., Bhave, P., Cass, G. R., and Prather, K. A.: Ambient single particle analysis in Riverside, California by aerosol time-of-flight mass spectrometry during the SCOS97-NARSTO, Atmos. Environ., 37, S239-S258, 2003.

Perry, K. D., Cliff, S. S., and Jimenez-Cruz, M. P.: Evidence for hygroscopic mineral dust particles from the Intercontinental Trans- 
port and Chemical Transformation Experiment, J. Geophys. Res., 109(D23), D23S28, doi:10.1029/2004JD004979, 2004.

Prospero, J. M. and Savoie, D. L.: Effect of continental sources on nitrate concentrations over the Pacific-Ocean, Nature, 339(6227), 687-689, 1989.

Pye, K.: Aeolian dusts and dust deposits, Academic Press, San Diego, 1987.

Qi, J., Feng, L., Li, X., and Zhang, M.: An X-ray photoelectron spectroscopy study of elements on the surface of aerosol particles, J. Aerosol Sci., 37(2), 218-227, 2006.

Quinn, P. K., Coffman, D. J., Bates, T. S., Welton, E. J., Covert, D. S., Miller, T. L., Johnson, J. E., Maria, S., Russell, L., Arimoto, R., Carrico, C. M., Rood, M. J., and Anderson, J.: Aerosol optical properties measured on board the Ronald H. Brown during ACE-Asia as a function of aerosol chemical composition and source region, J. Geophys. Res.-Atmos., 109(D19), D19S01, doi:10.1029/2003JD004010, 2004.

Rani, A., Prasad, D. S. N., Madnawat, P. V. S., and Gupta, K. S.: The role of free-fall atmospheric dust in catalyzing autoxidation of aqueous sulfur-dioxide, Atmos. Environ., Part A: General Topics, 26(4), 667-673, 1992.

Rosenfeld, D., Rudich, Y., and Lahav, R.: Desert dust suppressing precipitation: A possible desertification feedback loop, Proc. Natl. Acad. Sci. USA, 98(11), 5975-5980, 2001.

Rudich, Y., Khersonsky, O., and Rosenfeld, D.: Treating clouds with a grain of salt, Geophys. Res. Lett., 29(22), 2060, doi:10.1029/2002GL016055, 2002.

Santschi, C. and Rossi, M. J.: Uptake of $\mathrm{CO}_{2}, \mathrm{SO}_{2}, \mathrm{HNO}_{3}$ and $\mathrm{HCl}$ on calcite $\left(\mathrm{CaCO}_{3}\right)$ at $300 \mathrm{~K}$ : Mechanism and the role of adsorbed water, J. Phys. Chem. A, 110(21), 6789-6802, 2006.

Seinfeld, J. H., Carmichael, G. R., Arimoto, R., Conant, W. C., Brechtel, F. J., Bates, T. S., Cahill, T. A., Clarke, A. D., Doherty, S. J., Flatau, P. J., Huebert, B. J., Kim, J., Markowicz, K. M., Quinn, P. K., Russell, L. M., Russell, P. B., Shimizu, A., Shinozuka, Y., Song, C. H., Tang, Y. H., Uno, I., Vogelmann, A. M., Weber, R. J., Woo, J. H., and Zhang, X. Y.: ACE-ASIA - Regional climatic and atmospheric chemical effects of Asian dust and pollution, Bull. Amer. Meteorol. Soc., 85(3), 367-380, 2004.

Seisel, S., Borensen, C., Vogt, R., and Zellner, R.: Kinetics and mechanism of the uptake of $\mathrm{N}_{2} \mathrm{O}_{5}$ on mineral dust at $298 \mathrm{~K}$, Atmos. Chem. Phys., 5, 3423-3432, 2005, http://www.atmos-chem-phys.net/5/3423/2005/.

Shi, Z. B., Shao, L. T., Jones, T. P., and Lu, S. L.: Microscopy and mineralogy of airborne particles collected during severe dust storm episodes in Beijing, China, J. Geophys. Res., 110(D1), D01303, doi:10.1029/2004JD005073, 2005.

Silva, P. J., Carlin, R. A., and Prather, K. A.: Single particle analysis of suspended soil dust from Southern California, Atmos. Environ., 34(11), 1811-1820, 2000.

Song, C. H. and Carmichael, G. R.: The aging process of naturally emitted aerosol (sea-salt and mineral aerosol) during long range transport, Atmos. Environ., 33(14), 2203-2218, 1999.

Song, C. H. and Carmichael, G. R.: Gas-particle partitioning of nitric acid modulated by alkaline aerosol, J. Atmos. Chem., 40(1), $1-22,2001$

Song, C. H., Maxwell-Meier, K., Weber, R. J., Kapustin, V., and Clarke, A.: Dust composition and mixing state inferred from airborne composition measurements during ACE-Asia C130 Flight
\#6, Atmos. Environ., 39(2), 359-369, 2005.

Song, X. H., Hopke, P. K., Fergenson, D. P., and Prather, K. A.: Classification of single particles analyzed by ATOFMS using an artificial neural network, ART-2A, Anal. Chem., 71(4), 860-865, 1999.

Streets, D. G., Bond, T. C., Carmichael, G. R., Fernandes, S. D., Fu, Q., He, D., Klimont, Z., Nelson, S. M., Tsai, N. Y., Wang, M. Q., Woo, J. H., and Yarber, K. F.: An inventory of gaseous and primary aerosol emissions in Asia in the year 2000, J. Geophys. Res., 108(D21), 8809, doi:10.1029/2002JD003093, 2003.

Sullivan, R. C. and Prather, K. A.: Recent advances in our understanding of atmospheric chemistry and climate made possible by on-line aerosol analysis instrumentation, Anal. Chem., 77(12), 3861-3885, 2005.

Sullivan, R. C., Thornberry, T., and Abbatt, J. P. D.: Ozone decomposition kinetics on alumina: effects of ozone partial pressure, relative humidity and repeated oxidation cycles, Atmos. Chem. Phys., 4, 1301-1310, 2004,

http://www.atmos-chem-phys.net/4/1301/2004/.

Sun, J. M., Zhang, M. Y., and Liu, T. S.: Spatial and temporal characteristics of dust storms in China and its surrounding regions, 1960-1999: Relations to source area and climate, J. Geophys. Res.-Atmos., 106(D10), 10325-10333, 2001.

Tang, Y. H., Carmichael, G. R., Kurata, G., Uno, I., Weber, R. J., Song, C. H., Guttikunda, S. K., Woo, J. H., Streets, D. G., Wei, C., Clarke, A. D., Huebert, B., and Anderson, T. L.: Impacts of dust on regional tropospheric chemistry during the ACE-Asia experiment: A model study with observations, J. Geophys. Res., 109(D19), D19S21, doi:10.1029/2003JD003806, 2004a.

Tang, Y. H., Carmichael, G. R., Seinfeld, J. H., Dabdub, D., Weber, R. J., Huebert, B., Clarke, A. D., Guazzotti, S. A., Sodeman, D. A., Prather, K. A., Uno, I., Woo, J. H., Yienger, J. J., Streets, D. G., Quinn, P. K., Johnson, J. E., Song, C. H., Grassian, V. H., Sandu, A., Talbot, R. W., and Dibb, J. E.: Threedimensional simulations of inorganic aerosol distributions in east Asia during spring 2001, J. Geophys. Res., 109(D19), D19S23, doi:10.1029/2003JD004201, 2004b.

Thulasiraman, S., O’Neill, N. T., Royer, A., Holben, B. N., Westphal, D. L., and McArthur, L. J. B.: Sunphotometric observations of the 2001 Asian dust storm over Canada and the US, Geophys. Res. Lett., 29(8), 1255, doi:10.1029/2001GL014188, 2002.

Trochkine, D., Iwasaka, Y., Matsuki, A., Yamada, M., Kim, Y. S., Nagatani, T., Zhang, D., Shi, G. Y., and Shen, Z.: Mineral aerosol particles collected in Dunhuang, China, and their comparison with chemically modified particles collected over Japan, J. Geophys. Res.-Atmos., 108(D23), 8642, doi:10.1029/2002JD003268, 2003.

Turner, S. M., Harvey, M. J., Law, C. S., Nightingale, P. D., and Liss, P. S.: Iron-induced changes in oceanic sulfur biogeochemistry, Geophys. Res. Lett., 31(14), L14307, doi:10.1029/2004GL020296, 2004

Ullerstam, M., Johnson, M. S., Vogt, R., and Ljungstrom, E. DRIFTS and Knudsen cell study of the heterogeneous reactivity of $\mathrm{SO}_{2}$ and $\mathrm{NO}_{2}$ on mineral dust, Atmos. Chem. Phys., 3, 2043-2051, 2003, http://www.atmos-chem-phys.net/3/2043/2003/.

Ullerstam, M., Vogt, R., Langer, S., and Ljungstrom, E.: The kinetics and mechanism of $\mathrm{SO}_{2}$ oxidation by $\mathrm{O}_{3}$ on mineral dust, Phys. Chem. Chem. Phys., 4(19), 4694-4699, 2002. 
Underwood, G. M., Song, C. H., Phadnis, M., Carmichael, G. R., and Grassian, V. H.: Heterogeneous reactions of $\mathrm{NO}_{2}$ and $\mathrm{HNO}_{3}$ on oxides and mineral dust: A combined laboratory and modeling study, J. Geophys. Res., 106(D16), 18 055-18 066, 2001.

Usher, C. R., Michel, A. E., and Grassian, V. H.: Reactions on mineral dust, Chem. Rev., 103(12), 4883-4939, 2003 a.

Usher, C. R., Michel, A. E., Stec, D., and Grassian, V. H.: Laboratory studies of ozone uptake on processed mineral dust, Atmos. Environ., 37(38), 5337-5347, 2003b.

Vlasenko, A., Sjogren, S., Weingartner, E., Stemmler, K., Gaggeler, H. W., and Ammann, M.: Effect of humidity on nitric acid uptake to mineral dust aerosol particles, Atmos. Chem. Phys., 6, 21472160, 2006, http://www.atmos-chem-phys.net/6/2147/2006/.

Whiteaker, J. R. and Prather, K. A.: Hydroxymethanesulfonate as a tracer for fog processing of individual aerosol particles, Atmos. Environ., 37(8), 1033-1043, 2003.

Wu, P. M. and Okada, K.: Nature of coarse nitrate particles in the atmosphere - A single particle approach, Atmos. Environ., 28(12), 2053-2060, 1994.

Yermakov, A. N. and Purmal, A. P.: Iron-catalyzed oxidation of sulfite: From established results to a new understanding, Progress in Reaction Kinetics and Mechanism, 28(3), 189-255, 2003.

Yin, Y., Wurzler, S., Levin, Z., and Reisin, T. G.: Interactions of mineral dust particles and clouds: Effects on precipitation and cloud optical properties, J. Geophys. Res.-Atmos., 107(D23), 4724, doi:10.1029/2001JD001544, 2002.

Yuan, H., Rahn, K. A., and Zhuang, G.: Graphical techniques for interpreting the composition of individual aerosol particles, Atmos. Environ., 38(39), 6845-6854, 2004.
Zhang, D. Z. and Iwasaka, Y.: Nitrate and sulfate in individual Asian dust-storm particles in Beijing, China in spring of 1995 and 1996, Atmos. Environ., 33(19), 3213-3223, 1999.

Zhang, D. Z. and Iwasaka, Y.: Chlorine deposition on dust particles in marine atmosphere, Geophys. Res. Lett., 28(18), 3613-3616, 2001.

Zhang, D. Z. and Iwasaka, Y.: Size change of Asian dust particles caused by sea salt interaction: Measurements in southwestern Japan, Geophys. Res. Lett., 31(15), L15102, doi:10.1029/2004GL020087, 2004.

Zhang, D. Z., Iwasaka, Y., Shi, G. Y., Zang, J. Y., Matsuki, A., and Trochkine, D.: Mixture state and size of Asian dust particles collected at southwestern Japan in spring 2000, J. Geophys. Res.Atmos., 108(D24), 4760, doi:10.1029/2003JD003869, 2003.

Zhang, D. Z., Shi, G. Y., Iwasaka, Y., and Hu, M.: Mixture of sulfate and nitrate in coastal atmospheric aerosols: individual particle studies in Qingdao (36 degrees 04 ' N, 120 degrees 21' E), China, Atmos. Environ., 34(17), 2669-2679, 2000.

Zhu, X., Prospero, J. M., Millero, F. J., Savoie, D. L., and Brass, G. W.: The solubility of ferric ion in marine mineral aerosol solutions at ambient relative humidities, Mar. Chem., 38(1-2), 91-107, 1992.

Zhuang, G. S., Yi, Z., Duce, R. A., and Brown, P. R.: Link between iron and sulfur cycles suggested by detection of $\mathrm{Fe}(\mathrm{II})$ in remote marine aerosols, Nature, 355(6360), 537-539, 1992. 